\title{
Comparative Study of $\mathrm{SO}_{2}$ and $\mathrm{SO}_{2} / \mathrm{SO}_{3}$ Poisoning and Regeneration of $\mathrm{Cu} / \mathrm{BEA}$ and $\mathrm{Cu} / \mathrm{SSZ}-13$ for $\mathrm{NH}_{3} \mathrm{SCR}$
}

\author{
Xavier Auvray ${ }^{1} \cdot$ Maria Arvanitidou $^{1}$. Åsa Högström ${ }^{1} \cdot$ Jonas Jansson $^{2} \cdot$ Sheedeh Fouladvand $^{2} \cdot$ Louise Olsson $^{1}$ (i)
}

Received: 3 May 2021 / Revised: 15 September 2021 / Accepted: 10 October 2021 / Published online: 21 October 2021

(c) The Author(s) 2021

\begin{abstract}
Two copper-exchanged zeolites, $\mathrm{Cu} / \mathrm{SSZ}-13$ and Cu/BEA, were studied as catalysts for the selective reduction of $\mathrm{NO}_{x}$ by $\mathrm{NH}_{3}$ $\left(\mathrm{NH}_{3}-\mathrm{SCR}\right)$. Their activities for standard SCR $\left(\mathrm{NO}_{x}=\mathrm{NO}\right)$ and fast SCR $\left(\mathrm{NO}_{x}=50 \% \mathrm{NO}+50 \% \mathrm{NO}_{2}\right)$ were measured before

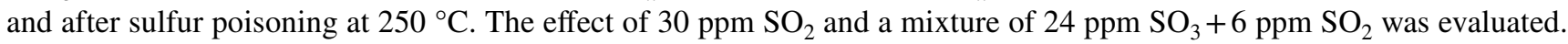
The repetition of subsequent activity measurements served as regeneration method in SCR conditions. $\mathrm{SO}_{2}$ deactivated $\mathrm{Cu} /$ SSZ-13 whereas $\mathrm{Cu} / \mathrm{BEA}$ was only moderately affected. $\mathrm{SO}_{3}$ led to stronger deactivation of both catalysts than $\mathrm{SO}_{2}$. However, also for this case, the $\mathrm{Cu} / \mathrm{BEA}$ was significantly less affected than $\mathrm{Cu} / \mathrm{SSZ}-13$, even though $\mathrm{Cu} / \mathrm{BEA}$ contained larger amount of stored sulfur. One possible reason for this could be the large pores of $\mathrm{Cu} / \mathrm{BEA}$, where the sulfur species possibly resulted in less sterical hindrance than in the small pore $\mathrm{SSZ}-13$ structure. $\mathrm{NH}_{3}$ temperature-programmed desorption $\left(\mathrm{NH}_{3}-\mathrm{TPD}\right)$ showed no loss of storage sites upon sulfur treatment and subsequent regeneration. Partial activity recovery was observed after a period in SCR conditions at $400{ }^{\circ} \mathrm{C}$ and $500{ }^{\circ} \mathrm{C}$. Temperature at $300{ }^{\circ} \mathrm{C}$ was insufficient to regenerate the catalysts. Diffuse reflectance infrared Fourier transform spectroscopy (DRIFTS) of NO adsorption suggested that $\mathrm{SO}_{2}$ interacts with the $\mathrm{ZCuOH}$ sites on $\mathrm{Cu} / \mathrm{SSZ}-13$, causing the strong poisoning.
\end{abstract}

Keywords $\mathrm{NH}_{3} \mathrm{SCR} \cdot$ Poisoning $\cdot \mathrm{SO}_{2}$ and $\mathrm{SO}_{3} \cdot \mathrm{Cu} /$ zeolites

\section{Introduction}

Diesel and lean-burn gasoline engines present the advantage to be more fuel-efficient and to emit less $\mathrm{CO}_{2}$ than gasoline engines. However, these combustion systems also produce nitrogen oxides $\left(\mathrm{NO}_{x}\right) . \mathrm{NH}_{3}$-SCR is an efficient process to reduce $\mathrm{NO}_{x}$ by $\mathrm{NH}_{3}$ over a metal-exchanged zeolite or $\mathrm{V}_{2} \mathrm{O}_{5}$-based catalyst. For automotive applications, $\mathrm{NH}_{3}$ can be produced in situ through decomposition and hydrolysis of a solution of urea sprayed in the exhaust gas.

The exhaust gas contains other chemical compounds that can interfere with the $\mathrm{NH}_{3}-\mathrm{SCR}$ process and deactivate the widely used, efficient, $\mathrm{Cu}$-exchanged zeolite catalyst. Sulfur oxides $\left(\mathrm{SO}_{x}\right)$ are impactful poisons which are therefore

Louise Olsson

louise.olsson@chalmers.se

1 Chemical Engineering, Competence Centre for Catalysis, Chalmers University of Technology, S-412 96 Gothenburg, Sweden

2 Volvo Group Trucks Technology, SE-405-08, Gothenburg, Sweden widely studied. Even at low concentration, the $\mathrm{SO}_{x}$ store and accumulate on the catalyst. They can block the active sites for the $\mathrm{NO}_{x}$ reduction reaction and decrease the catalytic performance with time [1-5]. This accumulation process requires periodic regeneration of the catalyst. Reducing conditions and high-temperature treatment can readily decompose the stored $\mathrm{SO}_{x}$ species. However, such reducing conditions at a high temperature may permanently damage the $\mathrm{Cu}$-exchanged zeolite catalyst [6]. To preserve the catalyst, it is important to further develop regeneration strategies for $\mathrm{SO}_{x}$-poisoned $\mathrm{SCR}$ catalysts.

Most of the $\mathrm{SO}_{x}$ poisoning and regeneration studies solely focus on the impact of $\mathrm{SO}_{2}$ as $\mathrm{SO}_{x}$ species and thermal regeneration $[3,5,7-12]$, sometimes carried out under reducing atmosphere. However, the $\mathrm{SO}_{2}$ present in the exhaust of a modern vehicle passes through an oxidation catalyst before reaching the SCR catalyst. The oxidation catalyst is a noble metal-based catalyst which oxidizes $\mathrm{CO}$ and hydrocarbons into $\mathrm{CO}_{2}$ and water vapor. It also oxidizes a large fraction of $\mathrm{NO}$ to $\mathrm{NO}_{2}$ and $\mathrm{SO}_{2}$ to $\mathrm{SO}_{3}$ [13-16]. The oxidation of $\mathrm{SO}_{3}$ occurs also on the $\mathrm{Cu} / \mathrm{SSZ}-13$ SCR catalyst itself from $450{ }^{\circ} \mathrm{C}$ [9]. Therefore, it is relevant to study the 
impact of a $\mathrm{SO}_{2} / \mathrm{SO}_{3}$ mixture on SCR catalysts because it is more representative of the real conditions. $\mathrm{SO}_{3}$ reacts readily with $\mathrm{NH}_{3}$ to form a solid salt that decomposes at a high temperature. Moreover, $\mathrm{SO}_{3}$ has shown a higher potential to store and deactivate the SCR catalyst than $\mathrm{SO}_{2}$ [17-19]. Simultaneous sulfur poisoning and thermal aging was studied by Wijayanti et al. [12] using $\mathrm{SO}_{2}$ and Tang et al. [20] using a $\mathrm{SO}_{x}$ mixture containing a large amount of $\mathrm{SO}_{3}$. Tang et al. [20] found that a hydrothermal pretreatment prior to sulfur exposure can decrease the deactivation of the SCR catalyst.

The zeolite structure also affects the sulfur aging for $\mathrm{Cu}$ / zeolites as found in one of our earlier studies, where $\mathrm{Cu} /$ SSZ-13 and Cu/LTA were compared during sulfur poisoning with $\mathrm{SO}_{2}$ [11]. However, there are according to the best of our knowledge no studies available where the effect of zeolite structure in $\mathrm{Cu} /$ zeolites is examined for sulfur poisoning using both $\mathrm{SO}_{2}$ and $\mathrm{SO}_{3}$ as a $\mathrm{SO}_{x}$ source. In this work, we therefore performed the comparative poisoning of two kinds of $\mathrm{Cu}$-exchanged zeolites with $\mathrm{SO}_{2}$ and a mixture of $\mathrm{SO}_{2} / \mathrm{SO}_{3}$. The influence of the zeolite structure (SSZ-13 and BEA) was thus studied and the impact of $\mathrm{SO}_{3}$ was determined and compared with the impact of $\mathrm{SO}_{2}$. The regeneration of poisoned catalyst was performed at various temperatures under realistic SCR conditions. Both the standard SCR and fast SCR activities were evaluated. The fresh and poisoned catalysts were characterized by XRD, ICP, and BET surface measurement.

\section{Experimental Methods}

\subsection{Catalyst Synthesis}

Two zeolite types were studied, where the BEA zeolite was commercial (Zeolyst International, $\mathrm{Si} / \mathrm{Al}=19$ ) while the SSZ-13 (chabazite structure) was synthesized. The SSZ-13 was chosen since $\mathrm{Cu} / \mathrm{SSZ}-13$ has been used for removing $\mathrm{NO}_{x}$ from diesel vehicles for several years [21]. In order to aid the understanding of the poisoning and regeneration ability of $\mathrm{Cu} / \mathrm{SSZ}-13$, we compare it with another $\mathrm{Cu} / \mathrm{zeo-}$ lite, namely $\mathrm{Cu} / \mathrm{BEA}$ due to the high activity of $\mathrm{Cu} / \mathrm{BEA}$ for $\mathrm{SCR}$ with $\mathrm{NH}_{3}$. It should be noted that $\mathrm{Cu} / \mathrm{BEA}$ is not commercially applicable due to thermal degradation [22] and hydrocarbon poisoning [23] issues and was chosen in this work for mechanistic reasons together with Cu/SSZ-13.

The chabazite structure was obtained by hydrothermal conversion of a faujasite zeolite. $\mathrm{NaOH}$ pellets (SigmaAldrich $>98 \%$ anhydrous pellets) were dissolved in deionized water (Millipore) to prepare a $1 \mathrm{M} \mathrm{NaOH}$ solution. Sodium trisilicate $\left(\mathrm{Na}_{2} \mathrm{SiO}_{3}, \mathrm{VWR}\right)$ and deionized water were added to the $\mathrm{NaOH}$ solution under stirring. The respective proportions used were $250 \mathrm{~g}$ and $320 \mathrm{~g}$ for a $200 \mathrm{~mL}$
$\mathrm{NaOH}$ solution. After $15 \mathrm{~min}$ stirring, $25 \mathrm{~g}$ of faujasite zeolite were added (Zeolyst International, CBV720). The solution was stirred for $30 \mathrm{~min}$ at room temperature before addition of $105 \mathrm{~g}$ of the structure-directing agent (SDA), N,N,N-trimethyl-1-adamantanamine iodide (TMAAI, ZeoGen SDA 2825). After 30 min under stirring at room temperature, the mixture was transferred to the Teflon liner of a stainless-steel autoclave (Parr Instrument Company) for hydrothermal treatment. The autoclave was then placed in a static oven at $140{ }^{\circ} \mathrm{C}$ for 6 days. The mixture was centrifugated to collect the solid zeolite. The zeolite was then washed with deionized water and again collected by centrifugation. The $\mathrm{pH}$ of the liquid after washing was measured and the washing process was repeated until this $\mathrm{pH}$ was neutral. The zeolite was dried at room temperature for at least $12 \mathrm{~h}$ and calcined for $8 \mathrm{~h}$ at $550{ }^{\circ} \mathrm{C}$ with a slow heating rate of $0.5^{\circ} \mathrm{C} / \mathrm{min}$. The sodium form of the zeolite $(\mathrm{Na} / \mathrm{SSZ}-13)$, where $\mathrm{Na}^{+}$cations counterbalance the negative charge of the aluminum, was thus obtained.

The next step in the catalyst preparation was ion exchange. Similar ion exchange procedure was applied to both BEA and CHA zeolites. Sodium ions were exchanged by ammonium ions with a solution of ammonium nitrate $(2 \mathrm{M})$ prepared by dissolving $\mathrm{NH}_{4} \mathrm{NO}_{3}$ (Sigma-Aldrich, $>99.0 \%$ ) in deionized water. The zeolite powder was poured into the ammonium nitrate solution $(33.33 \mathrm{~mL} / \mathrm{g}$ of zeolite $)$ and heated in an oil bath at $80{ }^{\circ} \mathrm{C}$ for $15 \mathrm{~h}$ under stirring. The powder was collected and washed as described previously. After drying at room temperature for at least $12 \mathrm{~h}$, a second exchange with $\mathrm{NH}_{4} \mathrm{NO}_{3}$ was performed in the same way. After washing and drying (12 $\mathrm{h}$ at room temperature), the zeolite was added to a copper nitrate solution $(0.2 \mathrm{M}$, $33.33 \mathrm{~mL} / \mathrm{g}$ of zeolite) for the copper exchange stage. The copper nitrate solution was prepared by dissolving copper nitrate hemi(penta-hydrate) $\left(\mathrm{CuN}_{2} \mathrm{O}_{6} \cdot 2.5 \mathrm{H}_{2} \mathrm{O}\right.$, SigmaAldrich) in deionized water. The mixture was maintained under vigorous stirring at $80{ }^{\circ} \mathrm{C}$ in an oil bath for $2 \mathrm{~h}$. After washing and drying, the $\mathrm{Cu}$-exchanged zeolite was calcined for $4 \mathrm{~h}$ at $550{ }^{\circ} \mathrm{C}$ with a heating rate of $5^{\circ} \mathrm{C} / \mathrm{min}$.

For activity studies and poisoning in synthetic gas bench reactor (SGB), catalyst-coated monoliths were prepared. The cordierite honeycomb substrate (Corning) had a channel density of $400 \mathrm{cpsi}$ and was calcined at $600{ }^{\circ} \mathrm{C}$ for $2 \mathrm{~h}$ prior to coating. The monoliths were $20 \mathrm{~mm}$ long with a diameter of $15 \mathrm{~mm}$ for a volume of ca. $3.5 \mathrm{~mL}$. The washcoat was made of $5 \mathrm{wt} \%$ boehmite (Disperal P2, Sasol) and 95wt\% catalyst. The washcoat powder was dispersed in a solution of $50 \mathrm{wt} \%$ deionized water and $50 \mathrm{wt} \%$ spectroscopic purity grade ethanol (Merck) with a liquid-to-solid mass ratio of 4 . The cordierite substrate was dipped into the slurry to fill up the channels. The solvent was evaporated under a hot air gun while rotating manually the sample to ensure homogeneous coating. The process was repeated until $300 \mathrm{mg}$ washcoat 
was loaded on the substrate. Finally, the samples were calcined in air at $500{ }^{\circ} \mathrm{C}$ for $2 \mathrm{~h}$.

\subsection{Characterization Methods}

The crystalline structure of the zeolites was examined by X-ray diffraction with a powder diffractometer (Siemens D5000) operating at $40 \mathrm{kV}$, using the $\mathrm{K} \alpha_{1}$ emission ray of a $\mathrm{Cu}$ anode as the X-ray source $(\lambda=1.54060 \AA)$. The X-ray diffraction angle was measured in the Bragg-Brentano geometry. The elemental composition of the catalyst was determined by ICP-AES (ALS Scandinavia). The specific surface area was measured by physisorption of $\mathrm{N}_{2}$ at $77 \mathrm{~K}$ with a Micromeritics Tri-Star 3000 and calculated according to the BET method.

\subsection{DRIFT Spectroscopy of NO Adsorption}

NO adsorption was conducted on degreened and $\mathrm{SO}_{2}$-poisoned monolithic catalysts treated in the flow reactor described below. The monoliths were crushed into a powder and then sieved to keep the particles fraction between 40 and $80 \mu \mathrm{m}$. The catalyst was placed in the sample holder of a heated Praying Mantis DRIFT cell (Harrick Scientific Products, Pleasantville, NY, USA) equipped with ZnSe windows and mounted on a Vertex 70 FTIR spectrometer (Bruker, Billerica, MA, USA) equipped with a liquid $\mathrm{N}_{2}$-cooled MCT detector. The spectra were recorded with a resolution of $4 \mathrm{~cm}^{-1}$. Before NO adsorption, the sample was firstly pretreated with $8 \% \mathrm{O}_{2}$ at $500{ }^{\circ} \mathrm{C}$ for $45 \mathrm{~min}$ and cooled to $30{ }^{\circ} \mathrm{C}$. Ar was then flushed over the sample for $60 \mathrm{~min}$ at $30{ }^{\circ} \mathrm{C}$ and a background spectrum was recorded under these conditions (32 scans). The total gas flow rate was always $50 \mathrm{~mL} / \mathrm{min}$ with Ar as balance gas. A total of $500 \mathrm{ppm}$ NO in $\mathrm{Ar}$ was then fed to the catalyst bed at $30^{\circ} \mathrm{C}$ for $60 \mathrm{~min}$. Spectra (12 scans) were recorded with a 5-min interval during NO adsorption.

\subsection{Reactor Setup}

These experiments were performed in a reactor made of a horizontal quartz tube heated by a resistance coil. The assembly was wrapped in quartz wool for insulation. The monolith was placed at ca. $9 \mathrm{~cm}$ from the tube outlet and wrapped in a layer of quartz wool to fill the void between the monolith and the reactor wall and thus avoid gas bypassing. Two thermocouples were inserted from the reactor outlet to record the intra-catalyst temperature and the inlet gas temperature (ca. $0.5 \mathrm{~cm}$ in front of the monolith). The thermocouple measuring the inlet gas temperature was used as feedback to regulate the reactor temperature. The gases were delivered by mass flow controllers (Bronkhorst) and the water vapor flow was generated by a controlled evaporator mixer (Bronkhorst). The outlet gas composition was quantitatively determined by a gas FTIR spectrometer equipped with a liquid $\mathrm{N}_{2}$-cooled MCT detector, a gas cell with a $5.11 \mathrm{~m}$ effective pathlength, and $\mathrm{ZnSe}$ windows (MultiGas 2030, MKS Instruments). The operating temperature of the spectrometer and of the inlet and outlet gas lines was $191^{\circ} \mathrm{C}$.

\subsection{Activity Measurements}

The samples were first subjected to a degreening step at $600{ }^{\circ} \mathrm{C}$ for $3 \mathrm{~h}$. The gas flow composition for the degreening was 400 ppm NO, $400 \mathrm{ppm} \mathrm{NH}_{3}, 8 \% \mathrm{O}_{2}$, and $5 \% \mathrm{H}_{2} \mathrm{O}$ balanced in Ar. After this, activity measurement was done in standard SCR conditions (400 ppm NO, 400 ppm $\mathrm{NH}_{3}$, $8 \% \mathrm{O}_{2}, 5 \% \mathrm{H}_{2} \mathrm{O}$ balanced in Ar) and fast SCR conditions (200 ppm NO, 200 ppm $\mathrm{NO}_{2}, 400$ ppm $\mathrm{NH}_{3}, 8 \% \mathrm{O}_{2}, 5 \%$ $\mathrm{H}_{2} \mathrm{O}$ balanced in $\mathrm{Ar}$ ). Prior to the standard and fast SCR activity measurements, the catalyst was pre-treated at $500{ }^{\circ} \mathrm{C}$ for $20 \mathrm{~min}$ in a gas flow of $8 \% \mathrm{O}_{2}$ and $5 \% \mathrm{H}_{2} \mathrm{O}$ balanced in Ar. This pre-treatment was not applied after poisoning to observe solely the effect of the regeneration in SCR conditions. The standard SCR activity was measured stepwise with a 30-min-long step at each temperature. When necessary, the steps were extended to $45 \mathrm{~min}$ to ensure steadystate measurement. For the degreened catalysts, the activity was measured at 100, 125, 150, 175, 200, 250, 300, 350, 400,450 , and $500{ }^{\circ} \mathrm{C}$. The fast SCR activity was measured at $175,200,250,300,350,400,450$, and $500^{\circ} \mathrm{C}$ with 45 -minlong steps. In all experiments, argon was used as carrier gas and the total flow rate was $1.2 \mathrm{~L} / \mathrm{min}\left(\mathrm{GHSV}=20,400 \mathrm{~h}^{-1}\right)$.

\section{$2.6 \mathrm{NH}_{3} \mathrm{TPD}$}

After degreening and activity measurement, temperatureprogrammed desorption of $\mathrm{NH}_{3}$ was conducted in the same reactor to measure the amount and strength of the different $\mathrm{NH}_{3}$ storage sites. The catalyst was exposed to $400 \mathrm{ppm} \mathrm{NH}_{3}$ and $5 \% \mathrm{H}_{2} \mathrm{O}$ in $\mathrm{Ar}$ for $90 \mathrm{~min}$ at $200{ }^{\circ} \mathrm{C}$. The catalyst was then flushed with $5 \% \mathrm{H}_{2} \mathrm{O}$ in $\mathrm{Ar}$ for $1 \mathrm{~h}$ at $200{ }^{\circ} \mathrm{C}$ before ramping the temperature at $10{ }^{\circ} \mathrm{C} / \mathrm{min}$ up to $600{ }^{\circ} \mathrm{C}$. $\mathrm{NH}_{3}$ TPD was also carried out after $\mathrm{SO}_{x}$ poisoning and regeneration (Fig. 1).

\subsection{Poisoning}

$\mathrm{SO}_{2}$ and $\mathrm{SO}_{2} / \mathrm{SO}_{3}$ poisoning was carried out for $6 \mathrm{~h}$ at $250{ }^{\circ} \mathrm{C}$ with a gas flow containing $30 \mathrm{ppm} \mathrm{SO}$, $400 \mathrm{ppm}$ $\mathrm{NO}, 8 \% \mathrm{O}_{2}$, and $5 \% \mathrm{H}_{2} \mathrm{O}$ balanced in $\mathrm{Ar}$. $\mathrm{NH}_{3}$ was preadsorbed on the catalyst for $30 \mathrm{~min}$ at $250{ }^{\circ} \mathrm{C}\left(800 \mathrm{ppm} \mathrm{NH}_{3}\right.$, $5 \% \mathrm{H}_{2} \mathrm{O}$ balanced in $\mathrm{Ar}$ ). $\mathrm{SO}_{3}$ was produced by oxidation of $\mathrm{SO}_{2}$ over a $7.7 \mathrm{wt} \% \mathrm{Pt} / \mathrm{Al}_{2} \mathrm{O}_{3}$ catalyst that was placed in a separate tubular reactor fed with $\mathrm{SO}_{2}, \mathrm{O}_{2}$ flows, and Ar. During $\mathrm{SO}_{2} / \mathrm{SO}_{3}$ poisoning, all gases passed through 
Fig. 1 Schematic diagram of the experimental procedure conducted on monolithic catalysts in $\mathrm{SGB}$ reactor. $\mathrm{SO}_{x}$ poisoning: 30 ppm SO$x, 400$ ppm NO, $8 \% \mathrm{O}_{2}, 5 \% \mathrm{H}_{2} \mathrm{O}$ balanced in Ar. Standard SCR: $400 \mathrm{ppm}$ $\mathrm{NO}, 400 \mathrm{ppm} \mathrm{NH}_{3}, 8 \% \mathrm{O}_{2}, 5 \%$ $\mathrm{H}_{2} \mathrm{O}$ balanced in Ar. Fast SCR: $200 \mathrm{ppm} \mathrm{NO}, 200 \mathrm{ppm} \mathrm{NO}_{2}$, $400 \mathrm{ppm} \mathrm{NH}_{3}, 8 \% \mathrm{O}_{2}, 5 \% \mathrm{H}_{2} \mathrm{O}$ balanced in $\mathrm{Ar}$

\begin{tabular}{|cll|}
\hline Fresh activity & - Degreening $3 \mathrm{~h}$, standard SCR conditions, $600^{\circ} \mathrm{C}$ \\
\hdashline Standard SCR $100,125,150,175,200,250,300,350$, \\
\hdashline $\mathrm{NH}_{3} \mathrm{TPD}$
\end{tabular}

the $\mathrm{SO}_{3}$ generator except $\mathrm{NO}$, water vapor, and argon used to carry water vapor. The $\mathrm{SO}_{3}$ generator temperature was set to $550{ }^{\circ} \mathrm{C}$ corresponding to a thermodynamic equilibrium of $80 \% \mathrm{SO}_{3}$. Assessment of the $\mathrm{SO}_{2}$ oxidation was made in an empty reactor. The concentrations measured at the outlet were $24 \mathrm{ppm} \mathrm{SO}_{3}$ and $6 \mathrm{ppm} \mathrm{SO}_{2}$ for a feed containing 30 ppm $\mathrm{SO}_{2}$ and $8 \% \mathrm{O}_{2}$ in Ar. The system was therefore able to generate $\mathrm{SO}_{3}$ according to the thermodynamic levels. The $\mathrm{SO}_{3}$ generator outlet was connected to the inlet line of the main reactor as close as possible to the reactor inlet and all lines were carefully heated with electrical heating bands. Ultra-low sulfur diesel (ULSD) contains a maximum mass fraction of $15 \mathrm{ppm}$ sulfur (in the USA). The combustion of such fuel emits $\mathrm{SO}_{2}$ in a concentration that inherently depends on the air-to-fuel ratio $(\mathrm{A} / \mathrm{F})$ and can be calculated. For diesel vehicles, $\mathrm{A} / \mathrm{F}$ varies a lot depending on driving conditions and engine load. Assuming $\mathrm{A} / \mathrm{F}=25$, the combustion of ULSD yields $\mathrm{SO}_{2}=0.518 \mathrm{ppmv}$. In these conditions, our poisoning corresponds to the sulfur emission of a ca. $300 \mathrm{~h}$ driving cycle. It should be noted that the assumed $\mathrm{A} / \mathrm{F}$ is rather low so the engine out $\mathrm{SO}_{2}$ concentration can be even lower.

\subsection{Regeneration}

The regeneration procedure consisted in repeating the standard and fast SCR activity measurements described previously. However, at each repetition of standard SCR, measurement steps were added at a higher temperature. Thus, the effect of the added temperature step, in SCR conditions, could affect the subsequent fast SCR and standard SCR activity measurements. A complete diagram of the experiments is shown in Fig. 1.

\section{Results and Discussion}

\subsection{Catalyst Characterization}

Table 1 shows the $\mathrm{Cu}$ loading and the $\mathrm{Si}$ and $\mathrm{Al}$ content of the catalysts according to ICP-AES measurements. $\mathrm{Cu} / \mathrm{SSZ}$ 13 exhibited a $\mathrm{Cu}$ loading of $1.7 \mathrm{wt} \%$ and a $\mathrm{Si} / \mathrm{Al}$ molar ratio of 17 which corresponds to a $\mathrm{Cu} / \mathrm{Al}$ ratio of 0.30 . The $\mathrm{Cu}$ loading of $\mathrm{Cu} / \mathrm{BEA}$ was $1.9 \mathrm{wt} \%$ and its $\mathrm{Si} / \mathrm{Al}$ ratio was 19 , corresponding to a $\mathrm{Cu} / \mathrm{Al}$ ratio of 0.39 . The sulfur loading 
Table 1 Elemental composition of $\mathrm{Cu} / \mathrm{SSZ}-13$ and $\mathrm{Cu} / \mathrm{BEA}$ determined by ICP-AES

\begin{tabular}{lll}
\hline Fresh powder & $\mathrm{Cu} / \mathrm{BEA}$ & $\mathrm{Cu} / \mathrm{SSZ}-13$ \\
\hline $\begin{array}{l}\text { Copper loading (wt } \%) \\
\mathrm{Si} / \mathrm{Al} \text { ratio }\end{array}$ & 1.9 & 1.7 \\
$\begin{array}{l}\left.\mathrm{S} \text { content after } \mathrm{SO}_{2} \text { poisoning (wt } \%\right) \\
\quad \begin{array}{l}\text { Crushed monolith (measured, based } \\
\text { on crushed monolith) }\end{array}\end{array}$ & 0.11 & 0.01 \\
$\begin{array}{c}\text { Catalyst washcoat (calculated, based } \\
\text { on only washcoat weight) }\end{array}$ & 0.45 & 0.04 \\
\hline
\end{tabular}

Table 2 BET surface area of fresh and $\mathrm{SO}_{2}$-poisoned $\mathrm{Cu} / \mathrm{SSZ}-13$ and $\mathrm{Cu} / \mathrm{BEA}$

\begin{tabular}{lll}
\hline BET surface area $\left(\mathrm{m}^{2} / \mathrm{g}\right)$ & $\mathrm{Cu} / \mathrm{BEA}$ & $\mathrm{Cu} / \mathrm{SSZ}-13$ \\
\hline Fresh calcined powder $^{*}$ & 621 & 692 \\
Degreened monolith $^{*}$ & 128 & 167 \\
Poisoned monolith $^{*}$ & 124 & 163 \\
\hline
\end{tabular}

*Crushed monolith, including both washcoat and cordierite

after $\mathrm{SO}_{2}$ poisoning was also measured on crushed monolithic samples specially prepared for characterization. They were degreened and treated with $\mathrm{SO}_{2}$ in the same reactor and according to the same procedure as the other samples used for activity measurements. It is clear that the Cu/BEA contained significantly more sulfur after poisoning compared to $\mathrm{Cu} / \mathrm{SSZ}-13$ (see Table 1).

Table 2 reports the BET surface area of the calcined fresh powders and the degreened and $\mathrm{SO}_{2}$-poisoned monoliths which were crushed for the analysis. For the calcined powders, the $\mathrm{Cu} / \mathrm{SSZ}-13$ exhibited a slightly higher BET surface area. Crushed monoliths had significantly lower surface area than its corresponding catalyst powder. This is due to the dilution of the catalyst with crushed cordierite, since the specific surface area of cordierite substrate was negligible $\left(0.7 \mathrm{~m}^{2} / \mathrm{g}\right)$. Moreover, the surface area before and after $\mathrm{SO}_{2}$ poisoning was similar for both catalysts, suggesting no significant blocking of the pores by sulfur deposits (Table 2). The sulfur content measured after $\mathrm{SO}_{2}$ poisoning confirmed the sulfur deposition on both catalysts.

Figure 2 shows the $\mathrm{X}$-ray diffractograms obtained with the $\mathrm{Cu} / \mathrm{SSZ}-13$ (a) and the Cu/BEA (b) catalysts. The diffractograms of the fresh powders are shown to evaluate the structure and the crystallinity. The diffractograms of the respective degreened and poisoned crushed monolith are shown with an offset. The diffractogram of the cordierite substrate is also given as a reference. Figure 2 a shows sharp peaks at $2 \theta=9^{\circ}, 13^{\circ}, 16^{\circ}, 18^{\circ}, 21^{\circ}, 25^{\circ}$, and $31^{\circ}$ corresponding to the chabazite structure $[5,6,24]$. Those characteristic peaks were detected with the degreened and $\mathrm{SO}_{2}$-poisoned monoliths which shows that the zeolite structure was not altered by the coating process, the degreening, and the poisoning. The results also clearly show that all FAU was converted to CHA during synthesis, since the peak at $6.3^{\circ}$ [25] is absent. Crystalline copper was not detected by XRD which rules out the presence of large copper particles. It rather suggests that copper is well-dispersed, as desired. Figure $2 \mathrm{~b}$ shows analogous results in the case of $\mathrm{Cu} / \mathrm{BEA}$. The fresh powder shows a broad feature at $2 \theta=7.6^{\circ}, 22.5^{\circ}$ corresponding to the BEA zeolite structure. No other diffraction peaks were detected, indicating that the copper was welldispersed. The BEA zeolite is partially disordered which is confirmed by the large width of the peaks measured. Like for SSZ-13, the degreening and the $\mathrm{SO}_{2}$ poisoning did not damage the structure of the BEA zeolite, which is in line with the surface area measurements (Table 2).

Figure 3 reports the $\mathrm{NH}_{3}$ release during $\mathrm{NH}_{3}$ TPD for the degreened, $\mathrm{SO}_{2}$-poisoned, and $\mathrm{SO}_{3}$-poisoned catalysts.
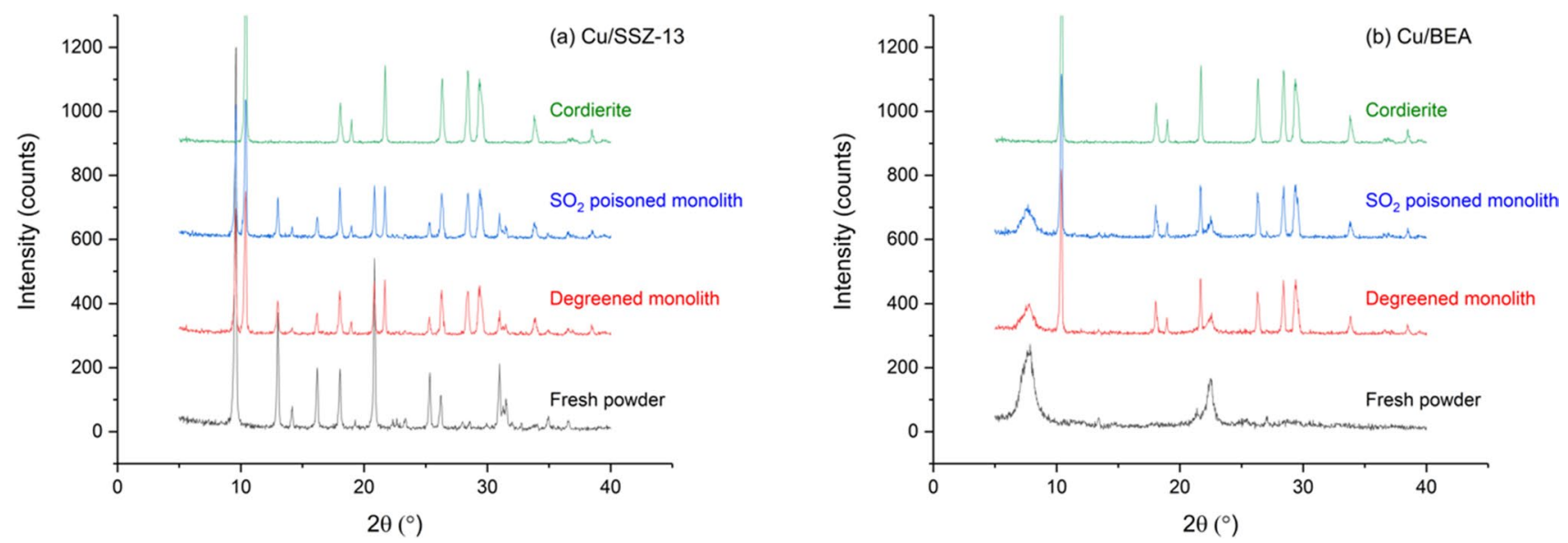

Fig. 2 XRD patterns of the fresh powders, the degreened crushed monoliths, and the $\mathrm{SO}_{2}$-poisoned crushed monoliths. a Cu/SSZ-13 and $\mathbf{b} \mathrm{Cu} /$ BEA 


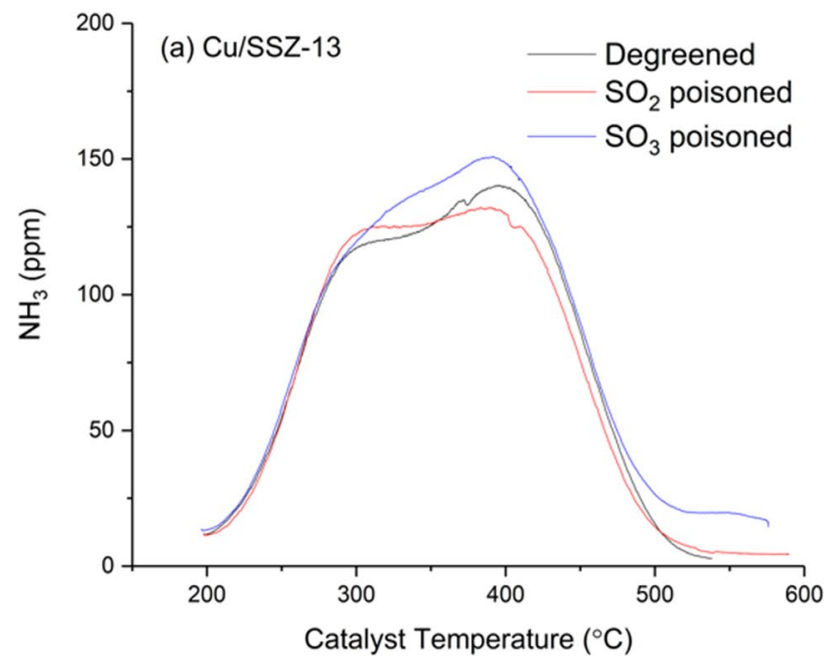

Fig. $3 \mathrm{NH}_{3}$-TPD profiles of degreened, $\mathrm{SO}_{2}$-poisoned (and regenerated), and $\mathrm{SO}_{3}$-poisoned (and regenerated) a Cu/SSZ-13 and $\mathbf{b ~} \mathrm{Cu} /$ BEA. Feed: $5 \% \mathrm{H}_{2} \mathrm{O}$ in $\mathrm{Ar}$, flowrate $=1.2 \mathrm{~L} / \mathrm{min}$, ramping rate: $10{ }^{\circ} \mathrm{C} /$

Figure 3a presents the typical binodal $\mathrm{NH}_{3}$ profile of $\mathrm{Cu} /$ SSZ-13, constituted of two main peaks. The low-temperature release, centered at $300{ }^{\circ} \mathrm{C}$, was assigned to $\mathrm{NH}_{3}$ adsorbed on exchanged copper ions which are Lewis acid sites [6, 26]. The high-temperature peak was assigned to $\mathrm{NH}_{3}$ adsorbed on the stronger sites, i.e., the Brønsted acid sites of the zeolite and, in lesser extent, the strongest of the Lewis sites $[6,27]$. The $\mathrm{NH}_{3}$ TPD after $\mathrm{SO}_{2}$ and $\mathrm{SO}_{3}$ poisoning was performed after all regeneration steps (see Fig. 1); thus, a large amount of sulfur was likely already removed. After $\mathrm{SO}_{2}$ poisoning and regeneration, the amount of $\mathrm{NH}_{3}$ stored was similar. However, $\mathrm{SO}_{2}$ poisoning slightly changed the binding strength, indicated by the larger low-temperature

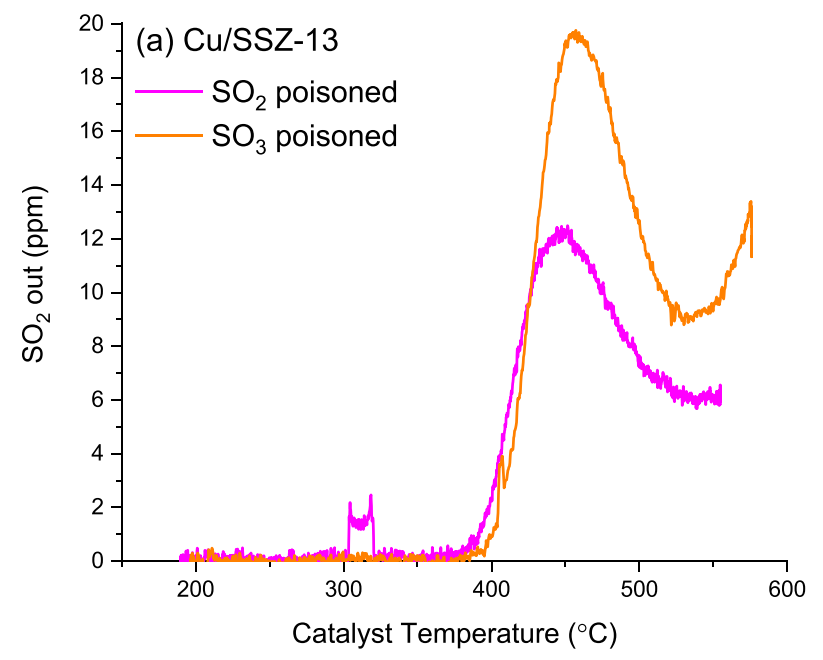

Fig. $4 \mathrm{SO}_{2}$ desorption during $\mathrm{NH}_{3}$-TPD carried out on $\mathrm{SO}_{2}$-poisoned (and regenerated) and $\mathrm{SO}_{3}$-poisoned (and regenerated) a Cu/SSZ-13 and $\mathbf{b} \mathrm{Cu} / \mathrm{BEA}$. Feed: $5 \% \mathrm{H}_{2} \mathrm{O}$ in Ar, flowrate $=1.2 \mathrm{~L} / \mathrm{min}$, ramping

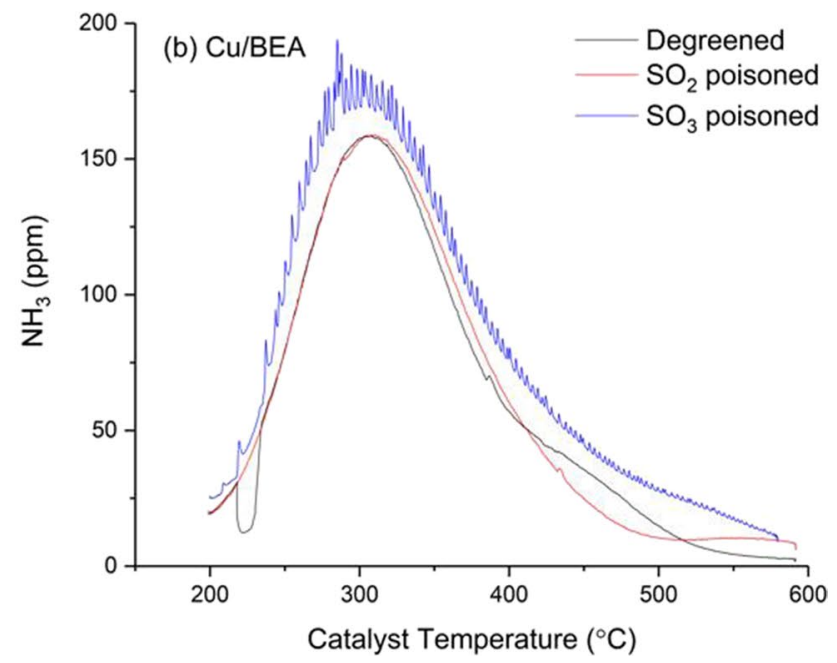

min. During $\mathrm{SO}_{2}$ poisoning, $30 \mathrm{ppm} \mathrm{SO}_{2}$ was used, and during $\mathrm{SO}_{3}$ poisoning, $24 \mathrm{ppm} \mathrm{SO} \mathrm{SO}_{3}$ and $6 \mathrm{ppm} \mathrm{SO}_{2}$, in the presence of $400 \mathrm{ppm}$ $\mathrm{NO}, 8 \% \mathrm{O}_{2}, 5 \% \mathrm{H}_{2} \mathrm{O}$ for both cases

peak and the smaller high-temperature peak. Wijayanti et al. [5] found that sulfur adsorption could induce new ammonia storage sites in $\mathrm{Cu} / \mathrm{SSZ}-13$, and this might be the reason for the small shift in binding strength of the ammonia in our results (see Fig. 3a). Interestingly, $\mathrm{SO}_{3}$ poisoning and regeneration increased the $\mathrm{NH}_{3}$ storage, which is in line with the results by Wijayanti et al. [5] and Brookshear et al. [8] using $\mathrm{SO}_{2}$. In addition, a desorption feature at $555^{\circ} \mathrm{C}$ was observed and was correlated to a sulfur release (Fig. 4a). The additional stored ammonia can have formed ammonium sulfate or ammonium bisulfate with the adsorbed sulfur [8, 28]. As shown in Fig. $4 \mathrm{a}, \mathrm{SO}_{2}$ was released during the $\mathrm{NH}_{3}$-TPD. Both $\mathrm{Cu} / \mathrm{SSZ}-13$ samples showed one peak at $400{ }^{\circ} \mathrm{C}$ and

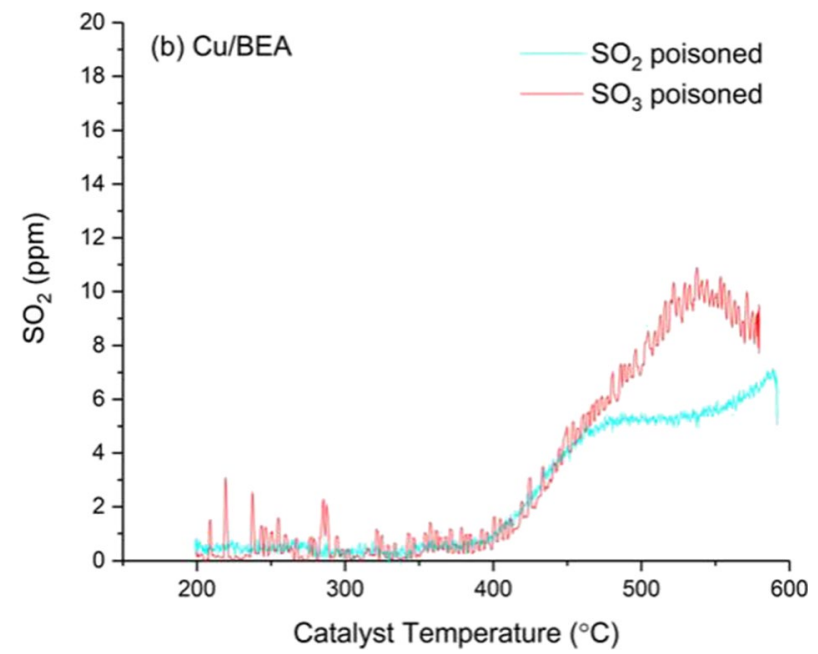

rate: $10{ }^{\circ} \mathrm{C} / \mathrm{min}$. During $\mathrm{SO}_{2}$ poisoning, $30 \mathrm{ppm} \mathrm{SO}_{2}$ was used, and during $\mathrm{SO}_{3}$ poisoning, $24 \mathrm{ppm} \mathrm{SO}_{3}$ and $6 \mathrm{ppm} \mathrm{SO}_{2}$, in the presence of $400 \mathrm{ppm} \mathrm{NO}, 8 \% \mathrm{O}_{2}, 5 \% \mathrm{H}_{2} \mathrm{O}$ for both cases 
the $\mathrm{SO}_{3}$-poisoned catalyst showed an additional incomplete peak starting to form at $550{ }^{\circ} \mathrm{C}$. This is consistent with the $\mathrm{SO}_{2}$ desorption observed by Wijayanti et al. [12] at 540 and $780{ }^{\circ} \mathrm{C}$, after $\mathrm{SO}_{2}$ poisoning of $\mathrm{Cu} / \mathrm{SSZ}-13$. The $\mathrm{SO}_{2}$ release measured was greater for the $\mathrm{SO}_{3}$-poisoned catalyst, indicating larger sulfur storage for the $\mathrm{SO}_{3}$ poisoned case. However, it should be noted that it is possible that the sulfates also are released as $\mathrm{SO}_{3}$ or $\mathrm{H}_{2} \mathrm{SO}_{4}$, but these species were not measured. The study of the stored sulfur species by Su et al. [4] revealed three distinct types of sulfur species, the thermal decomposition of which releases $\mathrm{SO}_{2}$. They observed desorption features peaking at 545,632 , and $772{ }^{\circ} \mathrm{C}$, assigned to $\mathrm{H}_{2} \mathrm{SO}_{4}, \mathrm{CuSO}_{4}$, and $\mathrm{Al}_{2}\left(\mathrm{SO}_{4}\right)_{3}$, respectively. Since we observe a sulfur desorption starting from $550{ }^{\circ} \mathrm{C}$, it could possibly be related to the decomposition of $\mathrm{H}_{2} \mathrm{SO}_{4}$ adsorbed on the catalyst, in line with the work by $\mathrm{Su}$ et al. [4].

The $\mathrm{NH}_{3}$-TPD of $\mathrm{Cu} / \mathrm{BEA}$ showed one main peak at $310^{\circ} \mathrm{C}$ and the degreened catalyst showed a shoulder at $450{ }^{\circ} \mathrm{C}$ which was absent after $\mathrm{SO}_{2}$ poisoning. A weak peak at $560{ }^{\circ} \mathrm{C}$ can be observed on the $\mathrm{SO}_{2}$-poisoned catalyst and a shoulder at $530{ }^{\circ} \mathrm{C}$ was present after $\mathrm{SO}_{3}$ poisoning. In general, the $\mathrm{NH}_{3}$ storage was not decreased with sulfur poisoning and regeneration. Like for $\mathrm{Cu} / \mathrm{SSZ}-13$, the $\mathrm{NH}_{3}$ release was even enhanced with $\mathrm{SO}_{3}$ exposure and small amounts of $\mathrm{SO}_{2}$ were released from $400{ }^{\circ} \mathrm{C}$ (Fig. 4b). A first $\mathrm{SO}_{2}$ peak appeared at $475^{\circ} \mathrm{C}$ on the $\mathrm{SO}_{2}$-poisoned $\mathrm{Cu} / \mathrm{BEA}$. This peak appeared as a shoulder on the $\mathrm{SO}_{3}$-poisoned $\mathrm{Cu}$ / BEA and was probably due to ammonium sulfate decomposition. A second peak was observed at $540{ }^{\circ} \mathrm{C}$ on the $\mathrm{SO}_{3}$-poisoned $\mathrm{Cu} / \mathrm{BEA}$ and at a temperature higher than $600{ }^{\circ} \mathrm{C}$ on the $\mathrm{SO}_{2}$-poisoned $\mathrm{Cu} / \mathrm{BEA}$. These peaks demonstrated the formation of different sulfate species such as $\mathrm{H}_{2} \mathrm{SO}_{4}, \mathrm{CuSO}_{4}$ depending on the sulfur feed used during

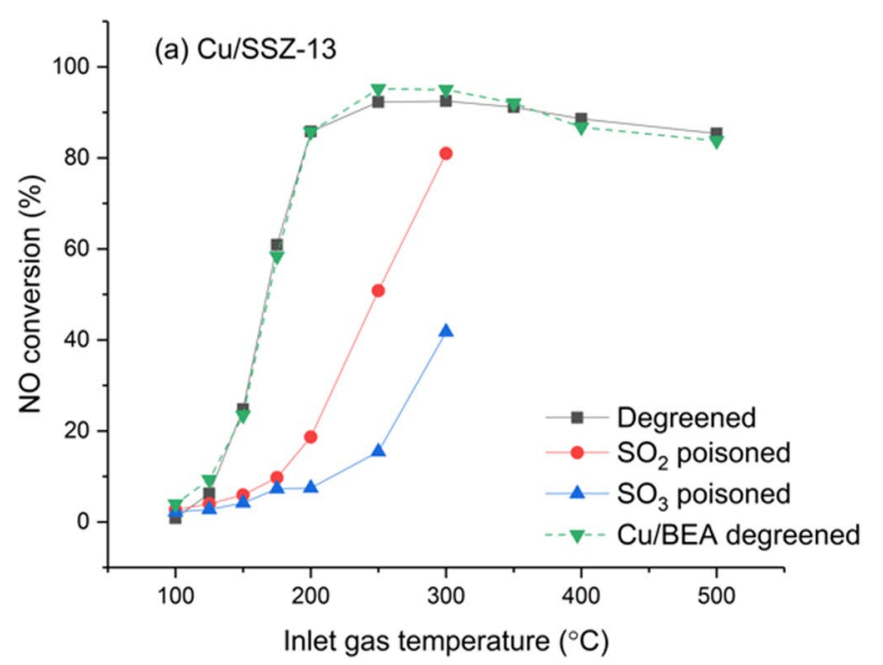

Fig. 5 Standard SCR activity (NO conversion) of degreened, $\mathrm{SO}_{2}$-poisoned, and $\mathrm{SO}_{3}$-poisoned $\mathbf{a} \mathrm{Cu} / \mathrm{SSZ}-13$ and $\mathbf{b} \mathrm{Cu} / \mathrm{BEA}$. Feed: $400 \mathrm{ppm} \mathrm{NO}, 400 \mathrm{ppm} \mathrm{NH}_{3}, 8 \% \mathrm{O}_{2}, 5 \% \mathrm{H}_{2} \mathrm{O}$ in $\mathrm{Ar}$, flowrate $=1.2 \mathrm{~L} /$ poisoning. This result is consistent with the influence of SCR conditions and $\mathrm{H}_{2} \mathrm{O}$ on the amount and partition of sulfate species demonstrated by $\mathrm{Su}$ et al. [4].

To summarize, the catalyst characterization indicates that the physical properties of the catalysts were almost unaffected by the $\mathrm{SO}_{x}$ treatments. The $\mathrm{SO}_{2}$ desorption observed during $\mathrm{NH}_{3}$-TPD at the end of the poisoning and regeneration procedure indicates that some stored sulfur species remained despite the regeneration.

\subsection{Standard SCR Activity for Degreened and Poisoned Samples}

Figure 5 is a comparative graph reporting the steady-state conversion of $\mathrm{NO}$ measured at several temperatures in the range of $100-500{ }^{\circ} \mathrm{C}$. The curves depict the standard SCR activity for the degreened catalysts, after $\mathrm{SO}_{2}$ poisoning and after $\mathrm{SO}_{3} / \mathrm{SO}_{2}$ poisoning (denoted $\mathrm{SO}_{3}$ poisoning). The activity of $\mathrm{Cu} / \mathrm{SSZ}-13$ is reported in Fig. 5a, which also includes the results for the degreened Cu/BEA. Both degreened catalysts show similar activity characterized by a low NO conversion below $150{ }^{\circ} \mathrm{C}$, a conversion greater than $90 \%$ between 250 and $350{ }^{\circ} \mathrm{C}$, and the slight decline of the conversion at $\mathrm{T}>350{ }^{\circ} \mathrm{C}$. After $\mathrm{SO}_{2}$ poisoning, the light-off temperature increased, but even more so after $\mathrm{SO}_{3}$ poisoning. For example, the NO conversion was $51 \%$ at $250{ }^{\circ} \mathrm{C}$ and $81 \%$ at $300{ }^{\circ} \mathrm{C}$ for $\mathrm{SO}_{2}$ poisoned $\mathrm{Cu} / \mathrm{SSZ}-13$, while after $\mathrm{SO}_{3} / \mathrm{SO}_{2}$ poisoning, the $\mathrm{NO}$ conversion at $300{ }^{\circ} \mathrm{C}$ was only $44 \%$. The results in Fig. 5a clearly demonstrate the high sensitivity of $\mathrm{Cu} / \mathrm{SSZ}-13$ to $\mathrm{SO}_{2}$ and, to a greater extent, to $\mathrm{SO}_{3}$. It should be noted that $\mathrm{N}_{2} \mathrm{O}$ was also formed during SCR, even more so during fast $\mathrm{SCR}$, and that $\mathrm{SO}_{2}$ and $\mathrm{SO}_{3}$ significantly decreased the $\mathrm{N}_{2} \mathrm{O}$ formation (data not shown).

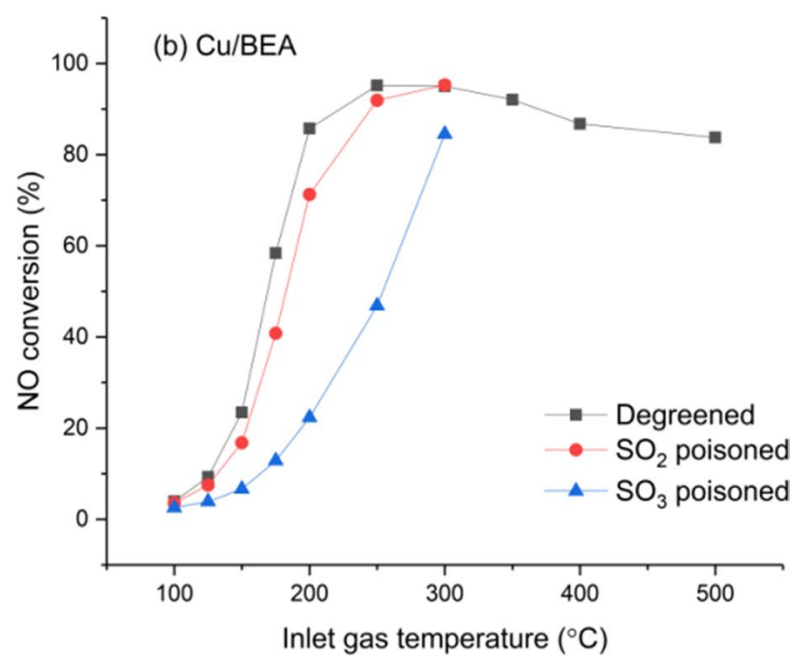

min. During $\mathrm{SO}_{2}$ poisoning, $30 \mathrm{ppm} \mathrm{SO}_{2}$ was used, and during $\mathrm{SO}_{3}$ poisoning, $24 \mathrm{ppm} \mathrm{SO}_{3}$ and $6 \mathrm{ppm} \mathrm{SO}_{2}$, in the presence of $400 \mathrm{ppm}$ $\mathrm{NO}, 8 \% \mathrm{O}_{2}, 5 \% \mathrm{H}_{2} \mathrm{O}$ for both cases 
The impact of $\mathrm{SO}_{2}$ and $\mathrm{SO}_{3}$ poisoning on the $\mathrm{SCR}$ activity of $\mathrm{Cu} / \mathrm{BEA}$ is compared in Fig. 5b. Also, for this catalyst, the $\mathrm{NO}$ conversion dropped at 175 and $200{ }^{\circ} \mathrm{C}$ after $\mathrm{SO}_{2}$ poisoning. However, the general impact of $\mathrm{SO}_{2}$ was moderate on $\mathrm{Cu} / \mathrm{BEA}$ and much less pronounced than on $\mathrm{Cu} / \mathrm{SSZ}-13$ despite the greater $\mathrm{SO}_{2}$ storage of $\mathrm{Cu} / \mathrm{BEA}$ (Table 1). One possible reason for this could be that since BEA has significantly larger pores, the adsorbed sulfur species causes less sterical hindrance for the reactants to access the $\mathrm{Cu}$ sites. Like for $\mathrm{Cu} / \mathrm{SSZ}-13, \mathrm{SO}_{3}$ poisoning was more detrimental than $\mathrm{SO}_{2}$ poisoning on $\mathrm{Cu} / \mathrm{BEA}$. The $\mathrm{SO}_{3}$-poisoned $\mathrm{Cu} / \mathrm{BEA}$ was again more active than the $\mathrm{SO}_{3}$-poisoned $\mathrm{Cu} / \mathrm{SSZ}-13$ with $86 \% \mathrm{NO}$ conversion at $300{ }^{\circ} \mathrm{C}$, compared with $44 \%$ for $\mathrm{Cu} / \mathrm{SSZ}-13$.

\subsection{Fast SCR Activity for Degreened and Poisoned Samples}

The selective reduction of an equimolar mixture of NO and $\mathrm{NO}_{2}$ with $\mathrm{NH}_{3}$ in presence of $\mathrm{O}_{2}$ is known as fast $\mathrm{SCR}$ due to its faster kinetics. These conditions are aimed by the upstream oxidation catalyst which converts $\mathrm{NO}$ to $\mathrm{NO}_{2}$ for a more efficient $\mathrm{NO}_{x}$ removal process. However, at a high temperature, this catalyst also converts $\mathrm{SO}_{2}$ to $\mathrm{SO}_{3}$. The fast SCR reaction was studied, and the activity is reported in Fig. 6 for $\mathrm{Cu} / \mathrm{SSZ}-13$ (a) and Cu/BEA (b). The NO conversion of the degreened $\mathrm{Cu} / \mathrm{SSZ}-13$ was close to $80 \%$ at $175{ }^{\circ} \mathrm{C}$ and increased to higher than $90 \%$ between 200 and $400{ }^{\circ} \mathrm{C}$. The activity declined below $80 \%$ at $500{ }^{\circ} \mathrm{C}$. Similar observations can be made for $\mathrm{Cu} / \mathrm{BEA}$ as seen in Fig. 6 . It can be noted that the $\mathrm{NO}$ conversion at low temperature

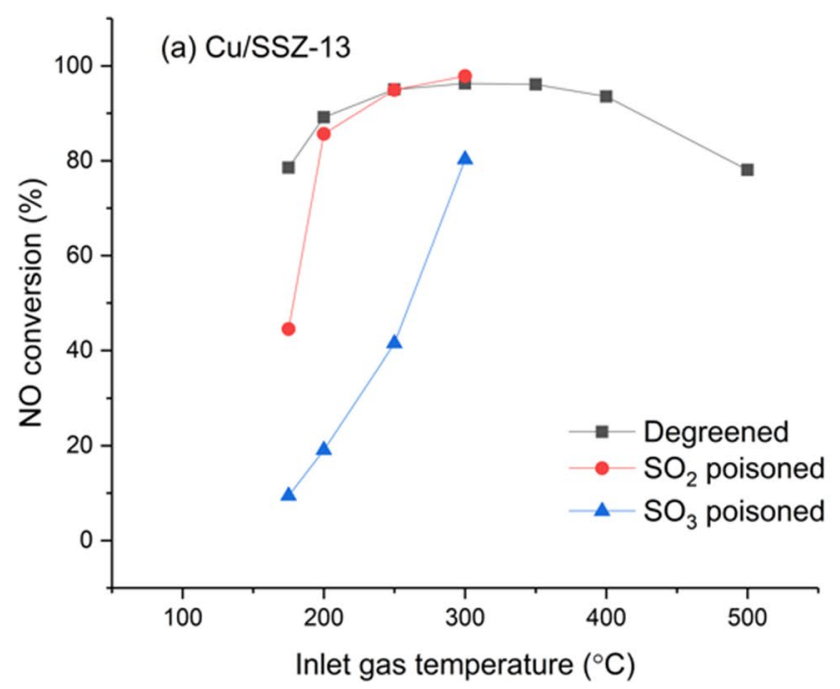

Fig. 6 Fast SCR activity (NO conversion) of degreened, $\mathrm{SO}_{2}$-poisoned, and $\mathrm{SO}_{3}$-poisoned $\mathbf{a} \mathrm{Cu} / \mathrm{SSZ}-13$ and $\mathbf{b} \mathrm{Cu} / \mathrm{BEA}$. Feed: $200 \mathrm{ppm} \mathrm{NO}, 200 \mathrm{ppm} \mathrm{NO} \mathrm{N}_{2}, 400 \mathrm{ppm} \mathrm{NH}_{3}, 8 \% \mathrm{O}_{2}, 5 \% \mathrm{H}_{2} \mathrm{O}$ in $\mathrm{Ar}$, flowrate $=1.2 \mathrm{~L} / \mathrm{min}$. Note: only $\mathrm{NO}$ conversion is shown, the $\mathrm{NO}_{2}$ was higher for the fast SCR than for the standard SCR. The $\mathrm{NO}_{2}$ conversion (not shown) was high (above $90 \%$ and for mid-range temperatures $100 \%$ ). The $\mathrm{SO}_{2}$ exposure led to a significant activity decrease of $\mathrm{Cu} / \mathrm{SSZ}-13$ below $200{ }^{\circ} \mathrm{C}$. However, the fast SCR was less impaired than the standard $\mathrm{SCR}$. The $\mathrm{SO}_{3}$ poisoning led to an even greater deactivation of $\mathrm{Cu} / \mathrm{SSZ}-13$ with a maximum NO conversion of only $80 \%$ at $300{ }^{\circ} \mathrm{C}$. As opposed to $\mathrm{Cu} / \mathrm{SSZ}-13, \mathrm{Cu} / \mathrm{BEA}$ was only mildly deactivated by $\mathrm{SO}_{2}$ and $\mathrm{SO}_{3}$ exposure (Fig. 6b). The lowest conversion for $\mathrm{Cu} / \mathrm{BEA}$, noted at $175{ }^{\circ} \mathrm{C}$, was $65 \%$ and $82 \%$ after $\mathrm{SO}_{2}$ poisoning and $\mathrm{SO}_{3}$ poisoning, respectively. It appeared clearly that $\mathrm{Cu} / \mathrm{SSZ}-13$ is more sensitive than $\mathrm{Cu} / \mathrm{BEA}$ to both $\mathrm{SO}_{2}$ and $\mathrm{SO}_{3}$ exposure. $\mathrm{Cu} / \mathrm{SSZ}-13$ is prone to severe deactivation when exposed to sulfur compounds, especially $\mathrm{SO}_{3}$. BEA is a type of zeolite characterized by wide channels constituted of 12-membered rings interconnected and forming cages [29]. SSZ-13, on the other hand, is a narrow-pore zeolite which consists of 6-membered rings forming hexagonal prisms (d6r) and chabazite cages (cha). The widest window of the chabazite cages is made of 8-membered rings with a $3.8 \AA$ diameter. The smaller channel opening and cage volume could be one reason why $\mathrm{Cu} /$ SSZ-13 is more prone to pore blocking by sulfate species than BEA and more subjected to deactivation by $\mathrm{SO}_{2}$ and $\mathrm{SO}_{3}$. $\mathrm{Cu} / \mathrm{SSZ}-13$ is preferred as an SCR catalyst for its better hydrothermal stability and lower hydrocarbon storage than $\mathrm{Cu} / \mathrm{BEA}$. However, our results show that SSZ-13 is more subjected to sulfur-induced deactivation than $\mathrm{Cu} / \mathrm{BEA}$. Since $\mathrm{SO}_{3}$ has a much larger effect than $\mathrm{SO}_{2}$ on $\mathrm{Cu} / \mathrm{SSZ}-13$, it would be beneficial to produce as little $\mathrm{SO}_{3}$ as possible. For a durable and optimal $\mathrm{NO}_{x}$ reduction, it is crucial to operate

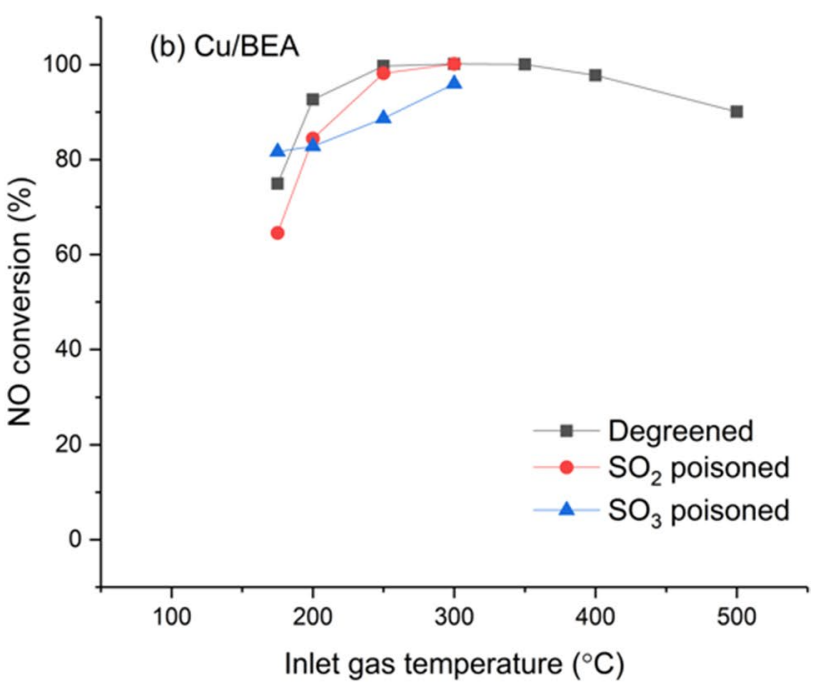

conversion was $100 \%$ at all temperature steps. During $\mathrm{SO}_{2}$ poisoning, $30 \mathrm{ppm} \mathrm{SO}_{2}$ was used, and during $\mathrm{SO}_{3}$ poisoning, $24 \mathrm{ppm} \mathrm{SO}_{3}$ and $6 \mathrm{ppm} \mathrm{SO}$, in the presence of $400 \mathrm{ppm} \mathrm{NO}, 8 \% \mathrm{O}_{2}, 5 \% \mathrm{H}_{2} \mathrm{O}$ for both cases 
in fast SCR conditions since $\mathrm{Cu} / \mathrm{SSZ}-13$ is less sensitive to $\mathrm{SO}_{2}$ and $\mathrm{SO}_{3}$ in fast $\mathrm{SCR}$ conditions than in standard SCR conditions.

The impact of $\mathrm{SO}_{2}$ exposure on fast SCR activity is moderate compared to its impact on standard SCR when the SCR unit is considered. However, taking the whole aftertreatment system into account that consists of an oxidation catalyst followed by the SCR converter, $\mathrm{SO}_{2}$ will affect the oxidation catalyst and inhibit its ability to oxidize $\mathrm{NO}$ to $\mathrm{NO}_{2}$ [14] which is necessary to perform the fast SCR on the SCR catalyst. Overall, $\mathrm{SO}_{2}$ exposure will decrease the $\mathrm{NO}_{2} / \mathrm{NO}_{x}$ ratio which will lower the amount of $\mathrm{NO}_{x}$ that can react in the fast SCR reaction. This will lead to an overall lower rate since a higher amount of NO needs to react in the slower standard SCR reaction.

\subsection{Regeneration in SCR Conditions: Standard SCR}

To desorb sulfur and restore the initial activity, hydrothermal treatment at a high temperature is usually advocated $[9,19]$. A reductive atmosphere is also beneficial to decompose the stored sulfur oxides [30]. However, such treatments affect the zeolite structure and the dispersion of active copper centers. High temperature in presence of water vapor is known to degrade the crystallinity of the zeolite structure, and at very high temperatures, the structure collapses [2, 31], which urges the development of highly stable zeolites. The detrimental effect of reducing treatment on the copper dispersion and the subsequent SCR activity has been revealed by Auvray et al. [6, 32]. It was shown that exchanged copper ions tend to agglomerate in larger particles under the

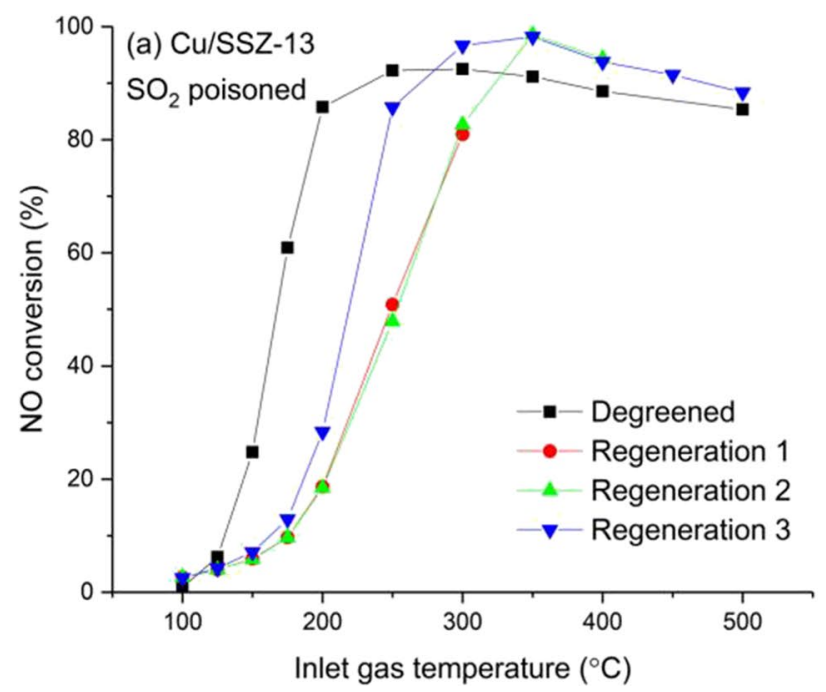

Fig. 7 Standard SCR activity (NO conversion) of degreened catalysts and during regeneration of $\mathrm{SO}_{2}$-poisoned $\mathbf{a} \mathrm{Cu} / \mathrm{SSZ}-13$ and $\mathbf{b}$ $\mathrm{Cu} / \mathrm{BEA}$. Feed: $400 \mathrm{ppm} \mathrm{NO}, 400 \mathrm{ppm} \mathrm{NH}_{3}, 8 \% \mathrm{O}_{2}, 5 \% \mathrm{H}_{2} \mathrm{O}$ in $\mathrm{Ar}$, flowrate $=1.2 \mathrm{~L} / \mathrm{min}$. Regeneration 1 is performed directly after the action of hydrogen. Therefore, in this study, the regeneration in lean SCR conditions at temperatures up to $500{ }^{\circ} \mathrm{C}$ was investigated. The stepwise activity measurement for standard and fast SCR was used and repeated after sulfur poisoning as a regeneration procedure. Each time the standard SCR activity was measured, the upper temperature boundary was increased from $300{ }^{\circ} \mathrm{C}$ for the first measurement after poisoning to 400 and $500{ }^{\circ} \mathrm{C}$ for the second and third measurements, respectively. Figure 7 presents the standard SCR activity of Cu/SSZ-13 (a) and Cu/BEA (b) after $\mathrm{SO}_{2}$ poisoning and regeneration in standard SCR conditions. For Cu/SSZ-13 (Fig. 7a), the NO conversion measured during the first repetition (denoted regeneration 2) was similar to the $\mathrm{NO}$ conversion measured after $\mathrm{SO}_{2}$ poisoning (denoted regeneration 1 ). Since the maximum temperature of the regeneration 1 stage was $300{ }^{\circ} \mathrm{C}$, this result indicates that no regeneration occurred in SCR conditions at $300^{\circ} \mathrm{C}$. However, a significant $\mathrm{NO}$ conversion improvement was noted for the second measurement repetition (regeneration 3 ) between 200 and $300{ }^{\circ} \mathrm{C}$. Before the regeneration 3 experiment, the poisoned catalyst was exposed to SCR conditions at $400{ }^{\circ} \mathrm{C}$ during the regeneration 2 . This result shows that partial regeneration of $\mathrm{SO}_{2}$-poisoned $\mathrm{Cu} / \mathrm{SSZ}-13$ occurred under SCR conditions at $400{ }^{\circ} \mathrm{C}$.

The NO conversion was also improved by the poisoning and regeneration compared to the degreened one at temperatures higher than $350{ }^{\circ} \mathrm{C}$. This has also been found for thermal aging [33] and could be due to larger deactivation of the ammonia oxidation reaction resulting in increased selectivity for the SCR reaction. The presence of SCR conditions is important for the sulfur regeneration, as previously

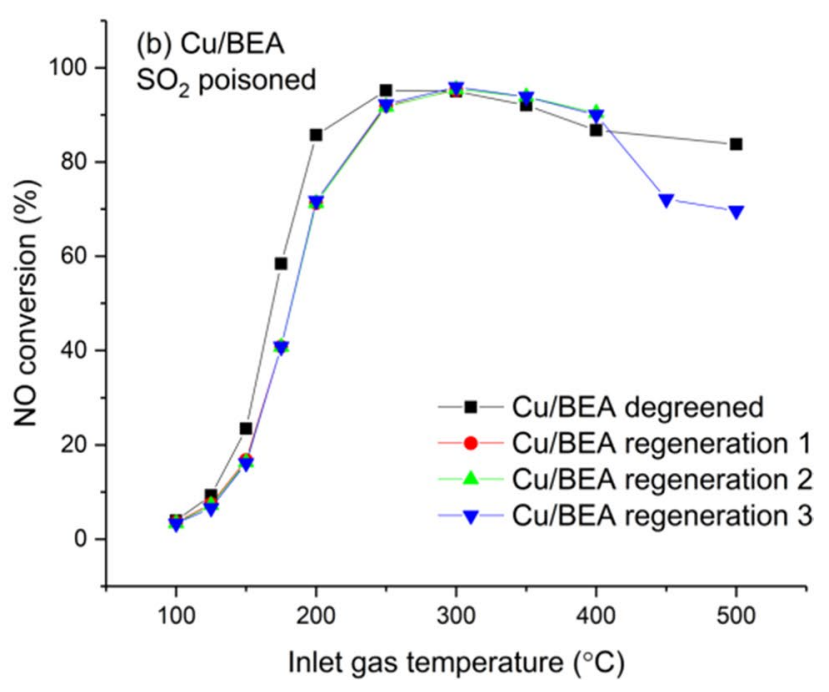

poisoning, thus showing the poisoned catalyst. Note that regeneration 1 and 2 for $\mathrm{Cu} / \mathrm{SSZ}-13$ and regeneration 1,2 , and 3 for $\mathrm{Cu} / \mathrm{BEA}$ are overlapping. During $\mathrm{SO}_{2}$ poisoning, $30 \mathrm{ppm} \mathrm{SO}_{2}$ was used in the presence of $400 \mathrm{ppm} \mathrm{NO}, 8 \% \mathrm{O}_{2}, 5 \% \mathrm{H}_{2} \mathrm{O}$ 
shown by Kumar et al. [30]. Moreover, Brookshear et al. [8] reported significant regeneration in lean conditions at $350{ }^{\circ} \mathrm{C}$ but obtained full activity recovery only with a DeSOx temperature of $500{ }^{\circ} \mathrm{C}$. Hammershøi et al. [19] found almost full recovery after regeneration in SCR conditions at $550{ }^{\circ} \mathrm{C}$. However, some remaining poisoning was still found after the $550{ }^{\circ} \mathrm{C}$ treatment in that study.

Sulfur poisoning and regeneration for $\mathrm{Cu} / \mathrm{BEA}$ are shown in Fig. $7 b$. The results show that $\mathrm{Cu} / \mathrm{BEA}$ was much less influenced by $\mathrm{SO}_{2}$ poisoning compared to $\mathrm{Cu} / \mathrm{SSZ}-13$, but also that the $\mathrm{Cu} / \mathrm{BEA}$ did not regain any activity during the regenerations up to $400{ }^{\circ} \mathrm{C}$. This result can indicate an irreversible deactivation caused by the $\mathrm{SO}_{2}$ poisoning to the catalyst or that higher temperatures are needed for the regeneration.

The effect of the regeneration of $\mathrm{SO}_{3}$-poisoned catalysts is shown in Fig. 8. Like after $\mathrm{SO}_{2}$ poisoning, the activity of $\mathrm{Cu} / \mathrm{SSZ}-13$ (Fig. 8a) was not recovered at all during the regeneration 2 (after SCR conditions up to $300{ }^{\circ} \mathrm{C}$ in regeneration 1) but was improved during the regeneration 3 . This indicates that partial regeneration of a $\mathrm{SO}_{3}$-poisoned $\mathrm{Cu}$ / SSZ-13 was possible at $400{ }^{\circ} \mathrm{C}$. Like after $\mathrm{SO}_{2}$ poisoning, the $\mathrm{NO}$ conversion at high temperatures $\left(>350{ }^{\circ} \mathrm{C}\right)$ was improved by the $\mathrm{SO}_{3} / \mathrm{SO}_{2}$ poisoning and the regeneration. After regeneration 3, the standard SCR activity of Cu/SSZ13 was significantly lower when the poisoning was carried out with the $\mathrm{SO}_{3} / \mathrm{SO}_{2}$ mixture than with $\mathrm{SO}_{2}$.

The $\mathrm{SO}_{3}$ poisoning impaired significantly the activity of $\mathrm{Cu} / \mathrm{BEA}$. In these conditions, the regeneration had a greater impact than on the $\mathrm{SO}_{2}$-poisoned $\mathrm{Cu} / \mathrm{BEA}$. Figure $8 \mathrm{~b}$ shows the partial activity recovery during regeneration 3 , indicating

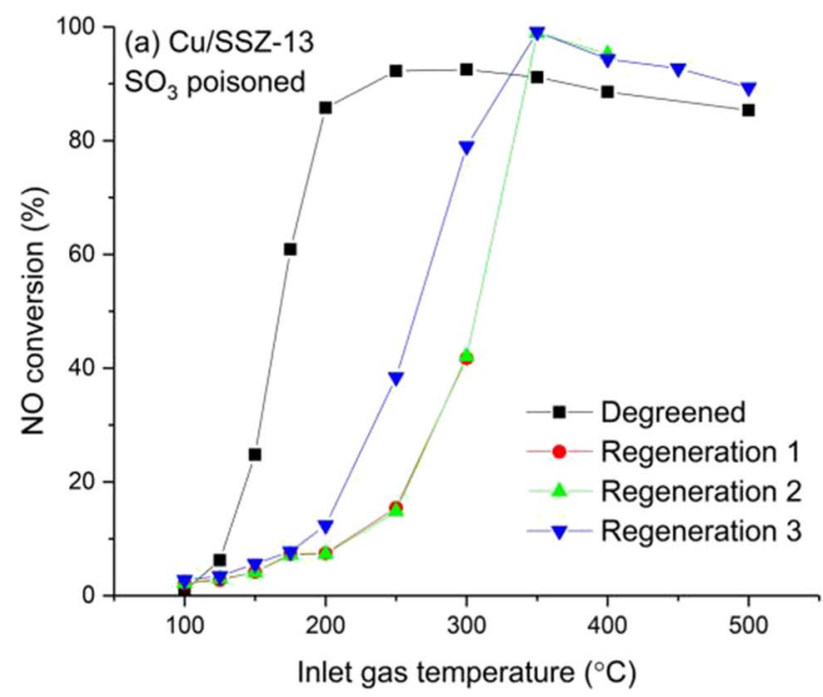

Fig. 8 Standard SCR activity (NO conversion) of degreened catalysts and during regeneration of $\mathrm{SO}_{3}$-poisoned a $\mathrm{Cu} / \mathrm{SSZ}-13$ and $\mathbf{b}$ $\mathrm{Cu} / \mathrm{BEA}$. Feed: $400 \mathrm{ppm} \mathrm{NO}, 400 \mathrm{ppm} \mathrm{NH}_{3}, 8 \% \mathrm{O}_{2}, 5 \% \mathrm{H}_{2} \mathrm{O}$ in $\mathrm{Ar}$, flowrate $=1.2 \mathrm{~L} / \mathrm{min}$. Regeneration 1 is performed directly after the that SCR conditions at $400{ }^{\circ} \mathrm{C}$ were able to partly reactivate $\mathrm{Cu} / \mathrm{BEA}$. This observation is similar for both $\mathrm{Cu} / \mathrm{SSZ}-13$ and $\mathrm{Cu} / \mathrm{BEA}$ after $\mathrm{SO}_{3} / \mathrm{SO}_{2}$ poisoning.

\subsection{Regeneration in SCR Conditions: Fast SCR}

The various sulfur species formed on the catalyst have different stability and affect different sites. The exchanged $\mathrm{Cu}$ attached to one $\mathrm{Al}$ center $(\mathrm{ZCuOH})$ was reported to be strongly affected upon sulfation of $\mathrm{Cu} / \mathrm{SSZ}-13$ [34]. Jangjou et al. [28] suggested that copper bisulfites form preferentially on $\mathrm{ZCuOH}$ while ammonium sulfates tend to form on $\mathrm{Cu}^{2+}$ connected to a pair of framework $\mathrm{Al}$ ( $\mathrm{Z} 2 \mathrm{Cu}$ sites). These two sites present different reactivity and roles in oxidation reactions and SCR. Therefore, the impact of sulfation and regeneration on the fast SCR was studied. Fast SCR activity measurements were part of the regeneration procedure (see Fig. 1). However, since full conversion of $\mathrm{NO}_{x}$ was reached at a rather low temperature, the measurements were limited to $300{ }^{\circ} \mathrm{C}$. Consequently, the impact of the fast SCR sequences on the sulfur regeneration was expected to be minor compared to the standard SCR steps. The fast SCR activity was measured four times after poisoning. It allowed us to probe the regeneration after each standard SCR step, whose maximum temperature was 300,400 , and $500{ }^{\circ} \mathrm{C}$, respectively. Figure 9 shows the NO conversion during fast SCR of the $\mathrm{SO}_{2}$-poisoned $\mathrm{Cu} / \mathrm{SSZ}-13$ (a) and $\mathrm{Cu} / \mathrm{BEA}$ (b). Figure $9 \mathrm{a}$ shows that regeneration 1 and 2 were similar for $\mathrm{Cu} / \mathrm{SSZ}-13$, indicating no regeneration during SCR at $300{ }^{\circ} \mathrm{C}$. However, fast SCR activity was regained during SCR at 400 and $500{ }^{\circ} \mathrm{C}$, as suggested by the regeneration 3

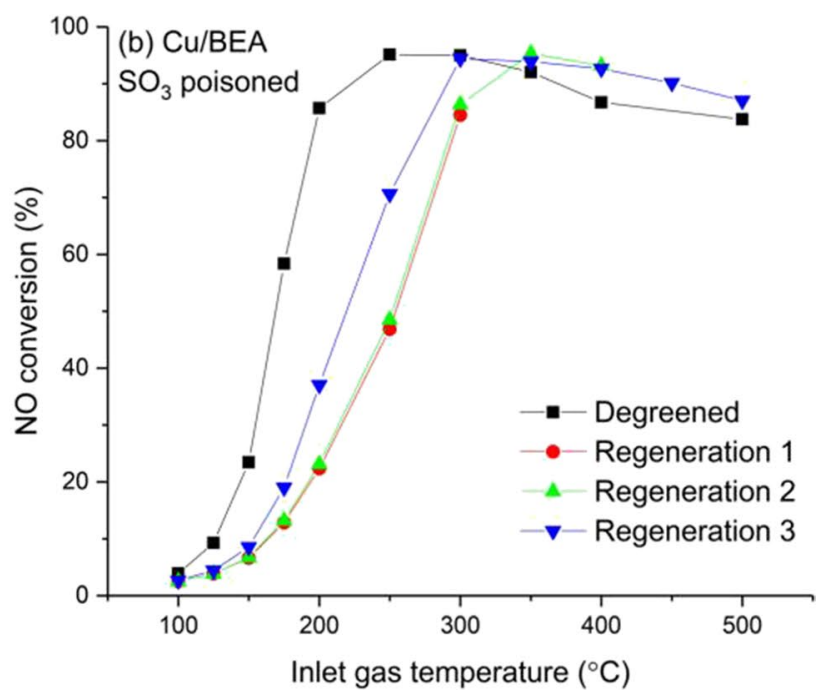

poisoning, thus showing the poisoned catalyst. During $\mathrm{SO}_{3}$ poisoning, $24 \mathrm{ppm} \mathrm{SO}_{3}$ and $6 \mathrm{ppm} \mathrm{SO}_{2}$, in the presence of $400 \mathrm{ppm} \mathrm{NO}, 8 \%$ $\mathrm{O}_{2}, 5 \% \mathrm{H}_{2} \mathrm{O}$ were used 


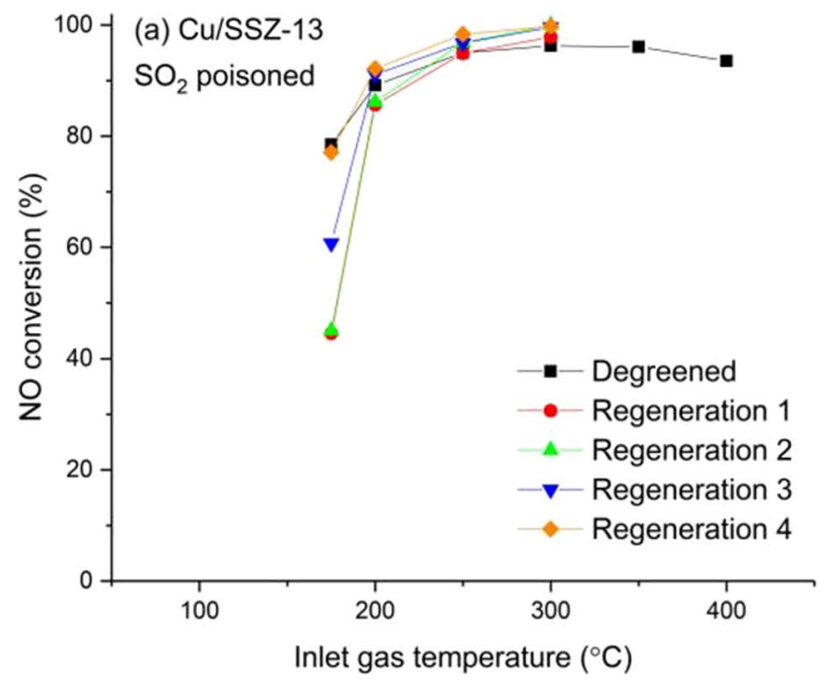

Fig. 9 Fast SCR activity (NO conversion) of degreened catalysts and during regeneration of $\mathrm{SO}_{2}$-poisoned a $\mathrm{Cu} / \mathrm{SSZ}-13$ and $\mathbf{b} \mathrm{Cu} / \mathrm{BEA}$. Feed: 200 ppm NO, 200 ppm NO 2,400 ppm $\mathrm{NH}_{3}, 8 \% \mathrm{O}_{2}, 5 \% \mathrm{H}_{2} \mathrm{O}$

and regeneration 4 measurements. The full activity recovery at $175^{\circ} \mathrm{C}$ can be noted during regeneration 4 . The improvement of the degreened activity can be noted as well between 200 and $300^{\circ} \mathrm{C}$. As for the standard SCR, the regeneration up to $400{ }^{\circ} \mathrm{C}$ was inefficient for the fast SCR on Cu/BEA (Fig. 9b) after $\mathrm{SO}_{2}$ poisoning; however, $\mathrm{Cu} / \mathrm{BEA}$ was also significantly less poisoned compared to $\mathrm{Cu} / \mathrm{SSZ}-13$.

The regeneration effect after $\mathrm{SO}_{3} / \mathrm{SO}_{2}$ poisoning was then examined for the fast SCR (Fig. 10). $\mathrm{SO}_{3}$ greatly decreased the fast SCR activity of $\mathrm{Cu} / \mathrm{SSZ}-13$ (Fig. 10a), but regeneration was possible in SCR conditions at 400 and $500{ }^{\circ} \mathrm{C}$,

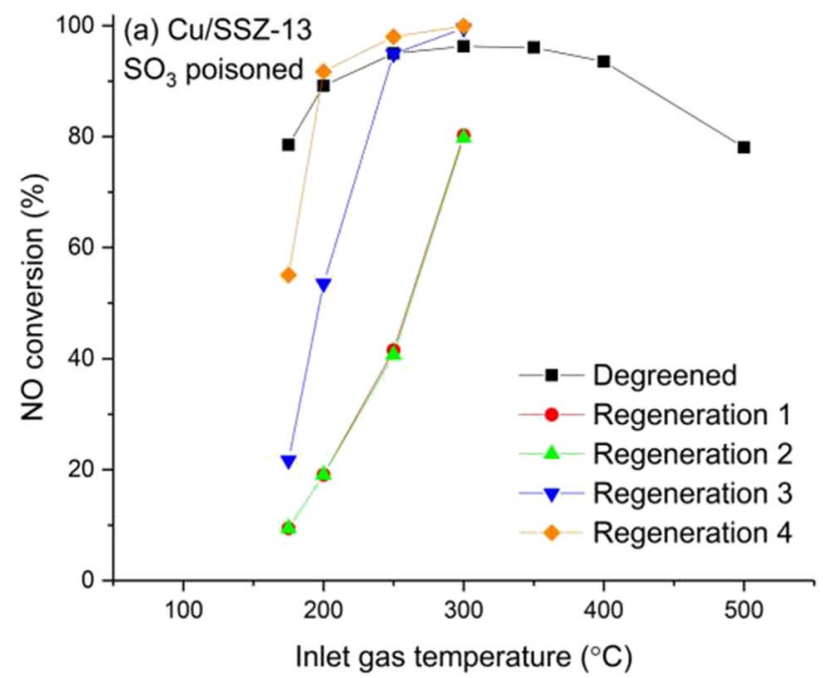

Fig. 10 Fast SCR activity (NO conversion) of degreened catalysts and during regeneration of $\mathrm{SO}_{3}$-poisoned $\mathbf{a} \mathrm{Cu} / \mathrm{SSZ}-13$ and $\mathbf{b} \mathrm{Cu} /$ BEA. Feed: 200 ppm NO, 200 ppm $\mathrm{NO}_{2}, 400$ ppm $\mathrm{NH}_{3}, 8 \% \mathrm{O}_{2}, 5 \%$

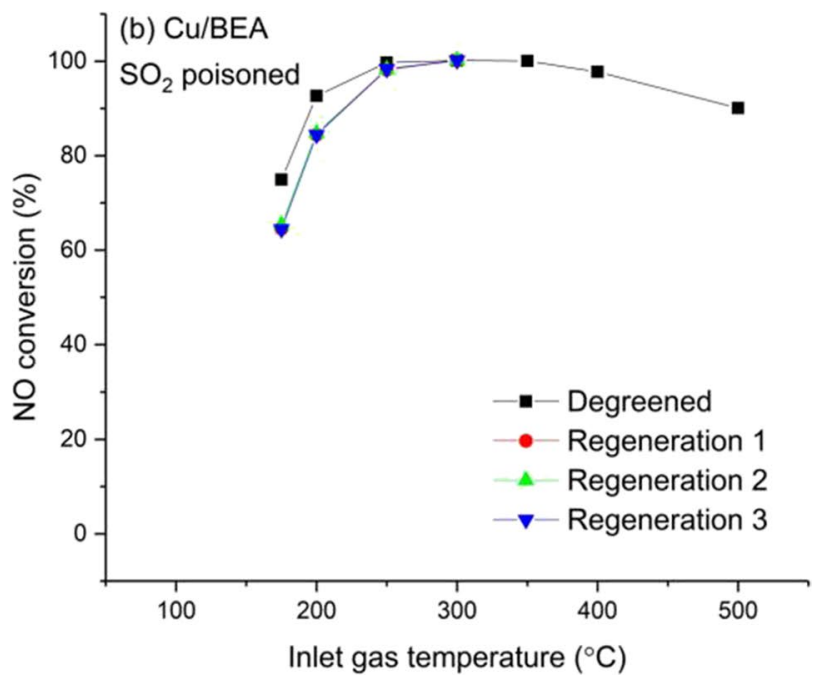

in $\mathrm{Ar}$, flowrate $=1.2 \mathrm{~L} / \mathrm{min}$. Regeneration 1 is standard SCR up to $300{ }^{\circ} \mathrm{C}$. During $\mathrm{SO}_{2}$ poisoning, $30 \mathrm{ppm} \mathrm{SO}_{2}$ was used in the presence of $400 \mathrm{ppm} \mathrm{NO}, 8 \% \mathrm{O}_{2}, 5 \% \mathrm{H}_{2} \mathrm{O}$

whereas $300{ }^{\circ} \mathrm{C}$ was not sufficient to observe any improvement. After regeneration 4, full recovery was not obtained at $175{ }^{\circ} \mathrm{C}$, indicating that some sulfur was remaining on the catalyst. Interestingly, the activity was greater than the degreened activity at a temperature between 200 and $300^{\circ} \mathrm{C}$. Sulfur poisoning results in the formation of different sulfur species such as $\mathrm{H}_{2} \mathrm{SO}_{4}, \mathrm{CuSO}_{4}, \mathrm{Al}_{2}\left(\mathrm{SO}_{4}\right)_{3}$ [4], and also ammonium sulfates (in the presence of ammonia). During mild regeneration, such as our regeneration, it is likely that some of the ammonium sulfates, which are less stable [12], are decomposed, while the more stable copper sulfates

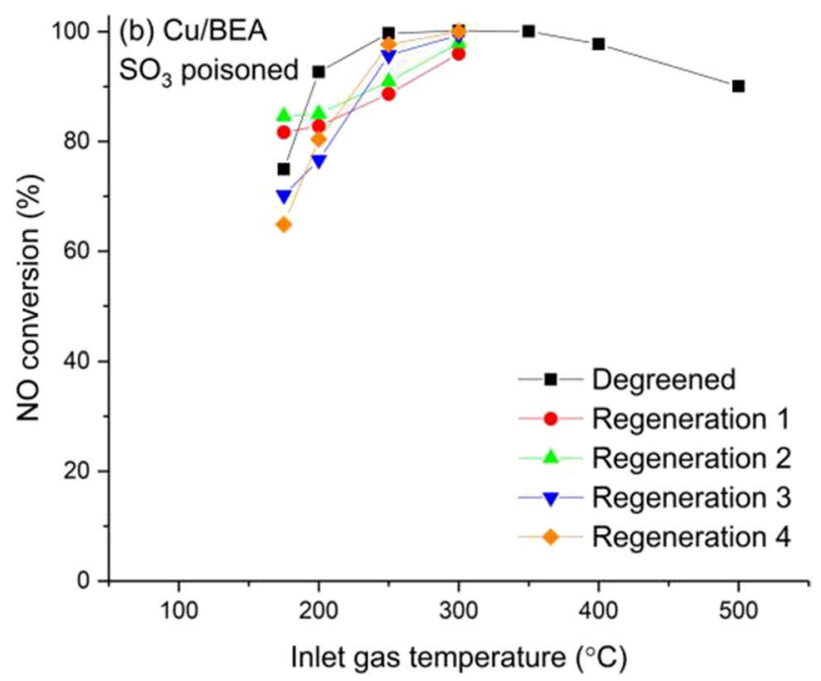

$\mathrm{H}_{2} \mathrm{O}$ in Ar, flowrate $=1.2 \mathrm{~L} / \mathrm{min}$. Regeneration 1 is standard SCR up to $300{ }^{\circ} \mathrm{C}$. During $\mathrm{SO}_{3}$ poisoning, $24 \mathrm{ppm} \mathrm{SO}_{3}$ and $6 \mathrm{ppm} \mathrm{SO}_{2}$ were used in the presence of $400 \mathrm{ppm} \mathrm{NO}, 8 \% \mathrm{O}_{2}, 5 \% \mathrm{H}_{2} \mathrm{O}$ for both cases 
remain. The formation of copper sulfates is increased in the presence of copper oxides [12], and copper oxides also enhance the ammonia oxidation. It is possible that the presence of copper sulfates reduces the competitive ammonia oxidation reaction and thereby increases the selectivity in the SCR process. Separate ammonia oxidation experiments (data not shown) show that some ammonia oxidation occurs at $300^{\circ} \mathrm{C}$, which could explain the increased SCR activity at $300{ }^{\circ} \mathrm{C}$, but not at $200{ }^{\circ} \mathrm{C}$. However, the $\mathrm{N}_{2} \mathrm{O}$ formation also decreased significantly during poisoning (data not shown), indicating that there is less ammonium nitrate formation after sulfur poisoning. Since ammonium nitrate formation hinders the SCR activity [35], we suggest that the reason for the increased SCR activity at low temperature could be related to that sulfur species blocks the ammonium nitrate formation, and thereby results in increased $\mathrm{NO}$ conversion. The $\mathrm{SO}_{3} / \mathrm{SO}_{2}$ exposure on $\mathrm{Cu} / \mathrm{BEA}$ (Fig. 10b) had a dual effect with a promotion at $175^{\circ} \mathrm{C}$ and poisoning at a higher temperature. These two features of the poisoned $\mathrm{Cu} / \mathrm{BEA}$ tended to disappear with the regeneration. Figure $10 \mathrm{~b}$ displays the global improvement during regeneration 2 and the degradation of the activity at $175{ }^{\circ} \mathrm{C}$ in regeneration 3 and 4. At the end of the process, however, the activity at 250 and $300{ }^{\circ} \mathrm{C}$ had retrieved its degreened level.

In general, $\mathrm{Cu} / \mathrm{SSZ}-13$ was more affected by $\mathrm{SO}_{2}$ and $\mathrm{SO}_{3} / \mathrm{SO}_{2}$ poisoning than $\mathrm{Cu} / \mathrm{BEA}$. This was clearly evidenced with $\mathrm{SO}_{2}$ poisoning since it only decreased moderately the SCR activity of $\mathrm{Cu} / \mathrm{BEA}$. However, in real conditions, $\mathrm{SO}_{3}$ is formed over the diesel oxidation catalyst and our results demonstrated that $\mathrm{SO}_{3}$ had a greater impact than $\mathrm{SO}_{2}$ on both $\mathrm{Cu} / \mathrm{SSZ}-13$ and $\mathrm{Cu} / \mathrm{BEA} . \mathrm{SO}_{3}$ exposure was able to decrease significantly the standard SCR of the $\mathrm{SO}_{2}$-resistant $\mathrm{Cu} / \mathrm{BEA}$ and the fast $\mathrm{SCR}$ activity of $\mathrm{Cu} /$
SSZ-13. Our results suggest the importance of adding $\mathrm{SO}_{3}$ during poisoning studies of SCR catalysts and in addition that the zeolite used plays a major role in the poisoning and regeneration. These results emphasize the need to study in detail the $\mathrm{SO}_{3}$ chemistry on the SCR catalysts. The regeneration in SCR operating conditions was possible to some extent whether the poisoning was performed using $\mathrm{SO}_{2}$ or $\mathrm{SO}_{3} / \mathrm{SO}_{2}$, which indicates the chemical and reversible nature of the poisoning.

\subsection{DRIFT Spectroscopy}

NO adsorption was performed on degreened and $\mathrm{SO}_{2}$-poisoned catalysts in a DRIFT cell. Figure $11 \mathrm{com}$ pares the FTIR spectra recorded after $55 \mathrm{~min}$ of NO exposure on $\mathrm{Cu} / \mathrm{SSZ}-13$ and $\mathrm{Cu} / \mathrm{BEA}$. On $\mathrm{Cu} / \mathrm{SSZ}-13$, the T-O-T structure vibration is disturbed by the exchanged $\mathrm{Cu}^{2+}$. Upon adsorption of a probe molecule such as $\mathrm{NO}$ or $\mathrm{NH}_{3}$ on $\mathrm{Cu}$, the T-O-T vibration bands appear as negative bands at approximately $900 \mathrm{~cm}^{-1}$ and $950 \mathrm{~cm}^{-1}$. These bands are known to correspond to the $\mathrm{Z} 2 \mathrm{Cu}$ and $\mathrm{ZCuOH}$ centers, respectively [11]. The inset of Fig. 11a shows that the ratio $\mathrm{ZCuOH} / \mathrm{Z} 2 \mathrm{Cu}$ was lower on the sulfated $\mathrm{Cu} / \mathrm{SSZ}-13$ than the degreened sample. These results indicate that stable sulfates were formed preferentially on the copper coordinated to one framework $\mathrm{Al}$ and one hydroxyl group $(\mathrm{ZCuOH})$. Thus, a part of these $\mathrm{ZCuOH}$ sites was blocked and unavailable to NO during the NO adsorption step. The decrease of the amount of $\mathrm{ZCuOH}$ upon sulfation was also observed by Tang et al. [20] and Luo et al. [34]. Shih et al. [3] reported on the higher $\mathrm{S}: \mathrm{Cu}$ molar ratio of $\mathrm{ZCuOH}$ than $\mathrm{Z} 2 \mathrm{Cu}$ sites indicating that $\mathrm{ZCuOH}$ was more prone to sulfation whereas $\mathrm{Z} 2 \mathrm{Cu}$ was rather insensitive to $\mathrm{SO}_{2}$ poisoning, which is in (a) Cu/SSZ-13

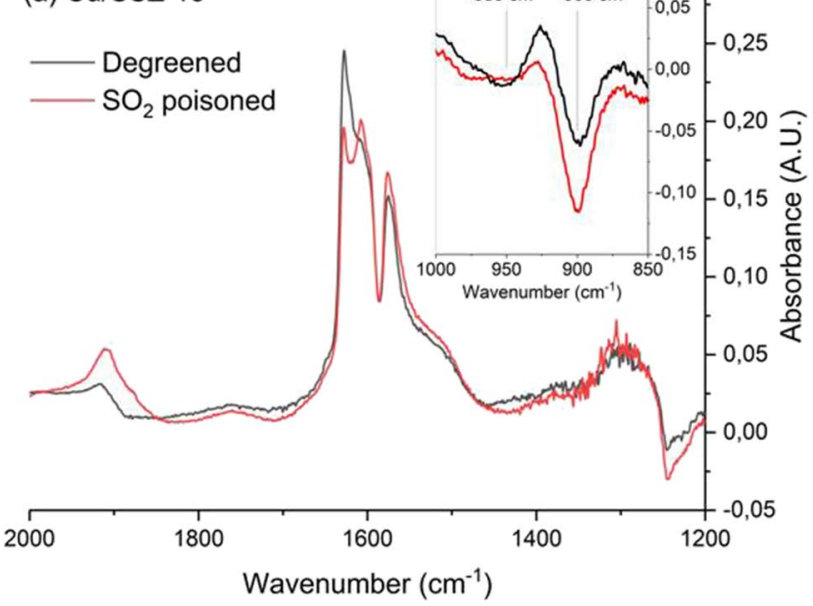

(b) Cu/BEA

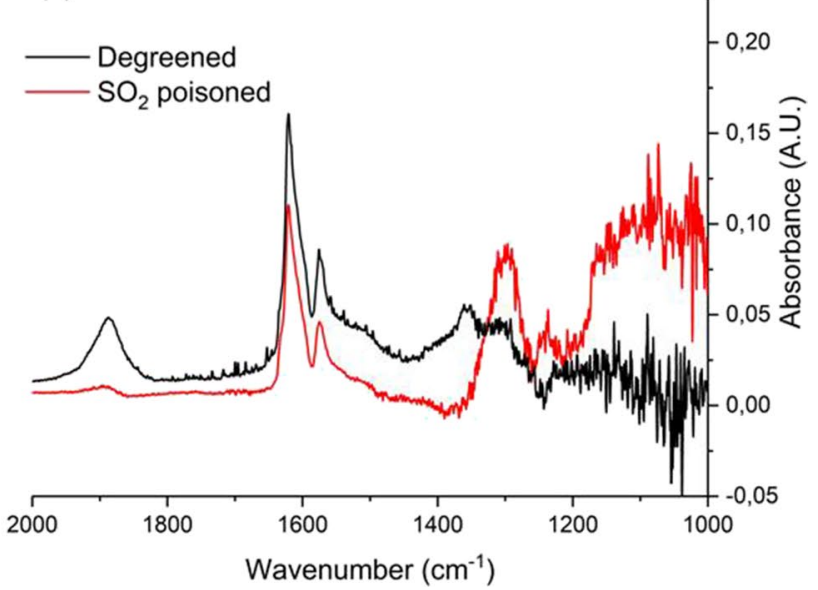

Fig. 11 DRIFT spectroscopy absorbance spectra of $\mathrm{NO}$ at $30{ }^{\circ} \mathrm{C}$ after oxidizing pretreatment at $500{ }^{\circ} \mathrm{C}$ of degreened and $\mathrm{SO}_{2}$-poisoned a $\mathrm{Cu} /$ SSZ-13 and b Cu/BEA catalysts. The spectra were recorded after 55 min of NO exposure 
line with our results. $\mathrm{ZCuOH}$ can readily form stable copper bisulfites and bisulfates in the presence of $\mathrm{SO}_{2}$ alone while the sulfation of $\mathrm{Z} 2 \mathrm{Cu}$ sites is obtained with cofeeding $\mathrm{SO}_{2}$ and $\mathrm{NH}_{3}$ to form ammonium sulfates [36]. Catalysts with a high $\mathrm{Si}: \mathrm{Al}$ ratio present a higher $\mathrm{ZCuOH}: \mathrm{Z} 2 \mathrm{Cu}$ and therefore are prone to formation of stable copper bisulfites that oxidize further to bisulfates. Catalysts with low $\mathrm{Si}: \mathrm{Al}$ are mainly deactivated by ammonium sulfates. Low-temperature deactivation occurs on $\mathrm{Cu} / \mathrm{SSZ}-13$ upon $\mathrm{SO}_{2}$ poisoning regardless of the $\mathrm{Si}: \mathrm{Al}$ ratio. However, the regeneration is greatly impacted by the nature of the inhibiting sulfate species. Therefore, regeneration of low $\mathrm{Si}: \mathrm{Al} \mathrm{Cu} / \mathrm{SSZ}-13$ can be achieved at relatively low temperature. Upon hydrothermal aging, $\mathrm{Cu}$ cations migrate through the CHA framework and it has been evidenced that $\mathrm{ZCuOH}$ is converted to the more stable $\mathrm{Z} 2 \mathrm{Cu}[20,23,34]$ located in the 6-member rings. In particular, Wei et al. [37] have demonstrated a decrease in sulfur storage and the mitigation of $\mathrm{SO}_{2}$ poisoning on mildly hydrothermally aged $\left(750{ }^{\circ} \mathrm{C}\right) \mathrm{Cu} / \mathrm{SSZ}-13$. The conversion of $\mathrm{ZCuOH}$ to $\mathrm{Z} 2 \mathrm{Cu}$ offers a greater resistance to $\mathrm{SO}_{2}$ poisoning and an improved SCR efficiency at high temperature because $\mathrm{ZCuOH}$ is active for $\mathrm{NH}_{3}$ oxidation. However, the SCR activity is lost at low temperature, which is very problematic. After higher hydrothermal aging temperature $\left(800{ }^{\circ} \mathrm{C}\right)$, Wijayanti et al. [12] also found a lower sulfur amount stored on the Cu/SSZ-13, but the formation of some copper oxides resulted in more stable copper sulfates being formed. In addition, copper oxides are less active for ammonia SCR reaction, which would reduce the catalyst efficiency.

The band at $1910 \mathrm{~cm}^{-1}$ could be assigned to NO adsorbed on $\mathrm{Cu}^{2+}$ (mononitrosyl group) [38-40]. It increased rapidly before decreasing slowly with time on the poisoned $\mathrm{Cu} /$ SSZ-13. The band at $1580 \mathrm{~cm}^{-1}$ can be assigned to a nitrate species adsorbed on $\mathrm{Cu}$ [38] while the bands at 1607 and $1628 \mathrm{~cm}^{-1}$ can be assigned to monodentate and bridging nitrates adsorbed on the zeolite framework, respectively [41]. $\mathrm{SO}_{2}$ poisoning affected these latter two bands by switching their relative ratio, increasing the monodentate/ bridged nitrate ratio. This result was consistent with the blocking of sites by sulfates since bridge nitrates required two sites.

NO adsorption on $\mathrm{Cu} / \mathrm{BEA}$ showed similarities with $\mathrm{Cu} /$ SSZ-13 (Fig. 11b) concerning the monodentate nitrate band at $1619 \mathrm{~cm}^{-1}$ and the nitrate on $\mathrm{Cu}^{2+}$ band at $1575 \mathrm{~cm}^{-1}$. The band assigned to NO adsorbed on $\mathrm{Cu}^{2+}$ was located at $1890 \mathrm{~cm}^{-1}$ on $\mathrm{Cu} / \mathrm{BEA}$. This band decreased rapidly when NO was turned off while the band at $1350 \mathrm{~cm}^{-1} \mathrm{kept}$ growing. The latter band was tentatively assigned to nitrite species. On the poisoned $\mathrm{Cu} / \mathrm{BEA}$, the $\mathrm{NO}-\mathrm{Cu}^{2+}$ band decreased during $\mathrm{NO}$ exposure after $30 \mathrm{~min}$. In addition, new bands at $1320 \mathrm{~cm}^{-1}$ and $1240 \mathrm{~cm}^{-1}$ and a broad band at $1100 \mathrm{~cm}^{-1}$ appeared. The bands at 1320 and $1240 \mathrm{~cm}^{-1}$ are tentatively assigned to different kinds of nitrates, which were more likely to form than nitrites on an oxidized surface. Negri et al. [42] observed a band at $1310 \mathrm{~cm}^{-1}$ during $\mathrm{NO}$ adsorption at $50{ }^{\circ} \mathrm{C}$ on $\mathrm{Cu}-\mathrm{CHA}$ that they assigned to a type of monodentate chelating nitrate on $\mathrm{Cu}$. The broad band at $1100 \mathrm{~cm}^{-1}$ is in the spectral region of sulfates [43-45]. This result suggests the conversion of sulfate species during $\mathrm{NO}$ adsorption on $\mathrm{SO}_{2}$-poisoned $\mathrm{Cu} / \mathrm{BEA}$. The growth of this sulfate species can be due to the mobility of a different sulfate species or the interaction with the adsorbed NO. This was not observed on poisoned $\mathrm{Cu} / \mathrm{SSZ}-13$ which indicates the more difficult reactivity and/or mobility of the sulfate species on $\mathrm{Cu} / \mathrm{SSZ}-13$ than on $\mathrm{Cu} / \mathrm{BEA}$. This result agrees with the activity measured after $\mathrm{SO}_{2}$ poisoning which showed a great negative impact on $\mathrm{Cu} / \mathrm{SSZ}-13$ and only a moderate activity loss on $\mathrm{Cu} / \mathrm{BEA}$.

\section{Conclusions}

The poisoning of $\mathrm{Cu} / \mathrm{BEA}$ and $\mathrm{Cu} / \mathrm{SSZ}-13$ with $\mathrm{SO}_{2}$ and a mixture of $\mathrm{SO}_{3}$ and $\mathrm{SO}_{2}\left(\mathrm{SO}_{3}: \mathrm{SO}_{2}=4\right)$ was studied on washcoated monoliths. After a degreening, $\mathrm{Cu} / \mathrm{SSZ}-13$ and $\mathrm{Cu} / \mathrm{BEA}$ showed similar SCR activities. It should be noted that $\mathrm{Cu} / \mathrm{BEA}$ is not commercially applicable and is used to compare with $\mathrm{Cu} / \mathrm{SSZ}-13$ for mechanistic reasons. The XRD analysis showed that the structure of the zeolites was not damaged by sulfur treatment. XRD analysis did not detect any large $\mathrm{Cu}$ particles either, which confirmed the absence of structural damages. The number and strength of acidic sites, determined by $\mathrm{NH}_{3}-\mathrm{TPD}$, were not strongly affected after poisoning and subsequent regeneration. Several regeneration treatments in SCR conditions were attempted in order to measure the degree of recovery.

There are both similarities and differences between the poisoning and regeneration of $\mathrm{Cu} / \mathrm{SSZ}-13$ and $\mathrm{Cu} / \mathrm{BEA}$. Firstly, both catalysts exhibited a decreased standard SCR activity after poisoning by $\mathrm{SO}_{2}$; however, $\mathrm{Cu} / \mathrm{SSZ}-13$ was significantly more deactivated. Interestingly, the $\mathrm{Cu} / \mathrm{BEA}$ contained more adsorbed sulfur after poisoning compared to $\mathrm{Cu} / \mathrm{SSZ}-13$. These results indicate that even though there were more sulfur available in $\mathrm{Cu} / \mathrm{BEA}$, it did not affect the activity equally much. One possible reason for this could be that the $\mathrm{Cu} / \mathrm{BEA}$ has significantly larger pores, so there could be less sterical hindrance by the sulfur addition. Moreover, the deactivation noted after $\mathrm{SO}_{3} / \mathrm{SO}_{2}$ poisoning was much more intense for both catalysts. $\mathrm{Cu} / \mathrm{BEA}$, however, was again less poisoned compared to $\mathrm{Cu} / \mathrm{SSZ}-13$.

Evaluation of standard SCR after regeneration revealed that $300{ }^{\circ} \mathrm{C}$ was not enough to regain any activity, while some regeneration was found for $\mathrm{Cu} / \mathrm{SSZ}-13$ after regeneration at $400{ }^{\circ} \mathrm{C}$. It should be noted that no regeneration was observed for this condition for $\mathrm{Cu} / \mathrm{BEA}$, but on the other 
hand, it was only mildly poisoned. $\mathrm{SO}_{3}$ poisoning was much more severe for both catalysts, but especially Cu/SSZ-13 . Both catalysts now exhibited some regeneration capabilities in SCR conditions at $400{ }^{\circ} \mathrm{C}$. Examining the fast SCR after different regenerations in standard SCR after $\mathrm{SO}_{2}$ poisoning showed that $\mathrm{Cu} / \mathrm{SSZ}-13$ could regain its full activity after regeneration at $500{ }^{\circ} \mathrm{C}$. After $\mathrm{SO}_{3}$ poisoning, much of the fast SCR activity was regained for both catalysts after $500{ }^{\circ} \mathrm{C}$ regeneration, but not all. Both catalysts exhibited less activity after $\mathrm{SO}_{3}$ poisoning and regeneration compared with fresh catalysts.

DRIFT spectroscopy revealed the interaction between sulfates and the $\mathrm{ZCuOH}$ sites of $\mathrm{Cu} / \mathrm{SSZ}-13$ which can explain the strong deactivation by blocking the active sites. Moreover, $\mathrm{Cu} / \mathrm{BEA}$ showed clear sulfate bands in DRIFT, which is consistent with the large amount of stored sulfur species by ICP measurements.

Funding Open access funding provided by Chalmers University of Technology. We received the financial support from the Swedish Research Council [Grant number 642-2014-5733].

\section{Declarations}

Conflict of Interest The authors declare that they have no competing interests.

Open Access This article is licensed under a Creative Commons Attribution 4.0 International License, which permits use, sharing, adaptation, distribution and reproduction in any medium or format, as long as you give appropriate credit to the original author(s) and the source, provide a link to the Creative Commons licence, and indicate if changes were made. The images or other third party material in this article are included in the article's Creative Commons licence, unless indicated otherwise in a credit line to the material. If material is not included in the article's Creative Commons licence and your intended use is not permitted by statutory regulation or exceeds the permitted use, you will need to obtain permission directly from the copyright holder. To view a copy of this licence, visit http://creativecommons.org/licenses/by/4.0/.

\section{References}

1. Olsson, L., Wijayanti, K., Leistner, K., Kumar, A., Joshi, S.Y., Kamasamudram, K., Currier, N.W., Yezerets, A.: A kinetic model for sulfur poisoning and regeneration of $\mathrm{Cu} / \mathrm{SSZ}-13$ used for $\mathrm{NH}_{3}$-SCR. Appl. Catal. B Environ. 183, 394-406 (2016)

2. Shan, Y., Shi, X., Yan, Z., Liu, J., Yu, Y., He, H.: Deactivation of Cu-SSZ-13 in the presence of $\mathrm{SO}_{2}$ during hydrothermal aging. Catal. Today 320, 84-90 (2019)

3. Shih, A.J., Khurana, I., Li, H., González, J., Kumar, A., Paolucci, C., Lardinois, T.M., Jones, C.B., Albarracin Caballero, J.D., Kamasamudram, K., Yezerets, A., Delgass, W.N., Miller, J.T., Villa, A.L., Schneider, W.F., Gounder, R., Ribeiro, F.H.: Spectroscopic and kinetic responses of $\mathrm{Cu}-\mathrm{SSZ}-13$ to $\mathrm{SO}_{2}$ exposure and implications for $\mathrm{NO}_{\mathrm{x}}$ selective catalytic reduction. Appl. Catal. A Gen. 574, 122-131 (2019)
4. Su, W., Li, Z., Zhang, Y., Meng, C., Li, J.: Identification of sulfate species and their influence on SCR performance of $\mathrm{Cu} / \mathrm{CHA}$ catalyst, Catalysis. Sci. Technol. 7, 1523-1528 (2017)

5. Wijayanti, K., Leistner, K., Chand, S., Kumar, A., Kamasamudram, K., Currier, N.W., Yezerets, A., Olsson, L.: Deactivation of $\mathrm{Cu}-\mathrm{SSZ}-13$ by $\mathrm{SO}_{2}$ exposure under SCR conditions, Catalysis. Sci. Technol. 6, 2565-2579 (2016)

6. Auvray, X., Grant, A., Lundberg, B., Olsson, L.: Lean and rich aging of a Cu/SSZ-13 catalyst for combined lean NOx trap (LNT) and selective catalytic reduction (SCR) concept, Cat. Sci. Technol. 9, 2152-2162, (2019)

7. Bergman, S.L., Dahlin, S., Mesilov, V.V., Xiao, Y., Englund, J., Xi, S., Tang, C., Skoglundh, M., Pettersson, L.J., Bernasek, S.L.: In-situ studies of oxidation/reduction of copper in $\mathrm{Cu}$ CHA SCR catalysts: comparison of fresh and SO2-poisoned catalysts, Appl. Catal. B Environ. 269, 118722, (2020

8. Brookshear, D.W., Nam, J.G., Nguyen, K., Toops, T.J., Binder, A.: Impact of sulfation and desulfation on NOx reduction using Cu-chabazite SCR catalysts. Catal. Today 258, 359-366 (2015)

9. Dahlin, S., Lantto, C., Englund, J., Westerberg, B., Regali, F., Skoglundh, M., Pettersson, L.J.: Chemical aging of Cu-SSZ-13 SCR catalysts for heavy-duty vehicles - influence of sulfur dioxide. Catal. Today 320, 72-83 (2019)

10. Jangjou, Y., Ali, M., Chang, Q., Wang, D., Li, J., Kumar, A., Epling, W.S.: Effect of $\mathrm{SO}_{2}$ on $\mathrm{NH}_{3}$ oxidation over a CuSAPO-34 SCR catalyst, Catalysis. Sci. Technol. 6, 2679-2685 (2016)

11. Wang, A., Olsson, L.: Insight into the $\mathrm{SO} 2$ poisoning mechanism for NOx removal by NH3-SCR over Cu/LTA and Cu/SSZ-13, Chem. Eng. J. 395, 125048 (2020)

12. Wijayanti, K., Xie, K., Kumar, A., Kamasamudram, K., Olsson, $\mathrm{L}$.: Effect of gas compositions on $\mathrm{SO}_{2}$ poisoning over $\mathrm{Cu} / \mathrm{SSZ}-13$ used for $\mathrm{NH}_{3}$-SCR. Appl. Catal. B Environ. 219, 142-154 (2017)

13. Auvray, X., Pingel, T., Olsson, E., Olsson, L.: The effect gas composition during thermal aging on the dispersion and $\mathrm{NO}$ oxidation activity over Pt/Al2O3 catalysts. Appl. Catal. B Environ. 129, 517-527 (2013)

14. Auvray, X.P., Olsson, L.: Sulfur dioxide exposure: a way to improve the oxidation catalyst performance. Ind. Eng. Chem. Res. 52, 14556-14566 (2013)

15. Koutsopoulos, S., Rasmussen, S.B., Eriksen, K.M., Fehrmann, R.: The role of support and promoter on the oxidation of sulfur dioxide using platinum based catalysts. Appl. Catal. A Gen. 306, 142-148 (2006)

16. Xue, E., Seshan, K., Ross, J.R.H.: Roles of supports, Pt loading and $\mathrm{Pt}$ dispersion in the oxidation of $\mathrm{NO}$ to $\mathrm{NO} 2$ and of $\mathrm{SO} 2$ to SO3. Appl. Catal. B Environ. 11, 65-79 (1996)

17. Kumar, A., Smith, M.A., Kamasamudram, K., Currier, N.W., An, H., Yezerets, A.: Impact of different forms of feed sulfur on smallpore Cu-zeolite SCR catalyst. Catal. Today 231, 75-82 (2014)

18. Cheng, Y., Montreuil, C., Cavataio, G., and Lambert, C., The Effects of SO2 and SO3 Poisoning on Cu/Zeolite SCR Catalysts, SAE Technical Paper 2009-01-0898, (2009)

19. Hammershøi, P.S., Jangjou, Y., Epling, W.S., Jensen, A.D., Janssens, T.V.W.: Reversible and irreversible deactivation of $\mathrm{Cu}-\mathrm{CHA}$ $\mathrm{NH}_{3}$-SCR catalysts by $\mathrm{SO}_{2}$ and $\mathrm{SO}_{3}$. Appl. Catal. B Environ. 226, 38-45 (2018)

20. Tang, Y.D., Wang, D., Wang, X., Zha, Y.H., An, H.M., Kamasamudram, K., Yezerets, A.: Impact of low temperature sulfur exposure on the aging of small pore $\mathrm{Cu}$-zeolite SCR catalyst. Catal. Today 360, 234-240 (2021)

21. Paolucci, C., Khurana, I., Parekh, A.A., Li, S.C., Shih, A.J., Li, H., Di Iorio, J.R., Albarracin-Caballero, J.D., Yezerets, A., Miller, J.T., Delgass, W.N., Ribeiro, F.H., Schneider, W.F., Gounder, R.: Dynamic multinuclear sites formed by mobilized copper ions in NOx selective catalytic reduction. Science 357, 898-903 (2017) 
22. Wilken, N., Wijayanti, K., Kamasamudram, K., Currier, N.W., Vedaiyan, R., Yezerets, A., Olsson, L.: Mechanistic investigation of hydrothermal aging of Cu-beta for ammonia SCR. Appl. Catal. B Environ. 111, 58 (2012)

23. Luo, J.Y., Oh, H., Henry, C., Epling, W.: Effect of C3H6 on selective catalytic reduction of $\mathrm{NOx}$ by $\mathrm{NH} 3$ over a Cu/zeolite catalyst: a mechanistic study. Appl. Catal. B Environ. 123, 296-305 (2012)

24. Blakeman, P.G., Burkholder, E.M., Chen, H.Y., Collier, J.E., Fedeyko, J.M., Jobson, H., Rajaram, R.R.: The role of pore size on the thermal stability of zeolite supported $\mathrm{Cu}$ SCR catalysts. Catal. Today 231, 56-63 (2014)

25. Valtchev, V., Rigolet, S., Bozhilov, K.N.: Gel evolution in a FAU-type zeolite yielding system at 90 degrees C. Microporous Mesoporous Mater. 101, 73-82 (2007)

26. Luo, J., Gao, F., Kamasamudram, K., Currier, N., Peden, C.H.F., Yezerets, A.: New insights into $\mathrm{Cu} / \mathrm{SSZ}-13 \mathrm{SCR}$ catalyst acidity. Part I: Nature of acidic sites probed by NH3 titration. J. Catal. 348, 291-299 (2017)

27. Leistner, K., Xie, K., Kumar, A., Kamasamudram, K., Olsson, L.: Ammonia desorption peaks can be assigned to different copper sites in Cu/SSZ-13. Catal. Lett. 147, 1882-1890 (2017)

28. Jangjou, Y., Sampara, C.S., Gu, Y., Wang, D., Kumar, A., Li, J., Epling, W.S.: Mechanism-based kinetic modeling of Cu-SSZ-13 sulfation and desulfation for $\mathrm{NH}_{3}$-SCR applications. React. Chem. Eng. 4, 1038-1049 (2019)

29. Treacy, M.M.J., Newsam, J.M.: Two new three-dimensional twelve-ring zeolite frameworks of which zeolite beta is a disordered intergrowth. Nature 332, 249-251 (1988)

30. Kumar, A., Smith, M.A., Kamasamudram, K., Currier, N.W., Yezerets, A.: Chemical deSO $\mathrm{S}_{\mathrm{x}}$ : an effective way to recover $\mathrm{Cu}$-zeolite SCR catalysts from sulfur poisoning. Catal. Today 267, 10-16 (2016)

31. Wang, D., Jangjou, Y., Liu, Y., Sharma, M.K., Luo, J., Li, J., Kamasamudram, K., Epling, W.S.: A comparison of hydrothermal aging effects on $\mathrm{NH}_{3}$-SCR of NOx over Cu-SSZ-13 and CuSAPO-34 catalysts. Appl. Catal. B Environ. 165, 438-445 (2015)

32. Auvray, X., Mihai, O., Lundberg, B., Olsson, L.: Deactivation of $\mathrm{Cu} / \mathrm{SSZ}-13 \mathrm{NH} 3-\mathrm{SCR}$ catalyst by exposure to $\mathrm{CO}, \mathrm{H} 2$, and $\mathrm{C} 3 \mathrm{H} 6$, Catalysts 9, 929, (2019)

33. Supriyanto, K., Wijayanti, A., Kumar, S., Joshi, K., Kamasamudram, N.W., Currier, A., Olsson, Y.L.: A global kinetic model for hydrothermal aging of $\mathrm{Cu}$ zeolites used in NH3 SCR. Appl. Catal. B Environ. 163, 382 (2015)

34. Luo, J., Wang, D., Kumar, A., Li, J., Kamasamudram, K., Currier, N., Yezerets, A.: Identification of two types of $\mathrm{Cu}$ sites in $\mathrm{Cu} / \mathrm{SSZ}$ 13 and their unique responses to hydrothermal aging and sulfur poisoning. Catal. Today 267, 3-9 (2016)
35. Leistner, K., Mihai, O., Wijayanti, K., Kumar, A., Kamasamudram, K., Currier, N.W., Yezerets, A., Olsson, L.: Comparison of $\mathrm{Cu} / \mathrm{BEA}, \mathrm{Cu} / \mathrm{SSZ}-13$ and $\mathrm{Cu} / \mathrm{SAPO}-34$ for ammonia-SCR reactions. Catal. Today 258, 49-55 (2015)

36. Jangjou, Y., Do, Q., Gu, Y.T., Lim, L.G., Sun, H., Wang, D., Kumar, A., Li, J.H., Grabow, L.C., Epling, W.S.: Nature of $\mathrm{Cu}$ active centers in $\mathrm{Cu}-\mathrm{SSZ}-13$ and their responses to $\mathrm{SO} 2$ exposure. ACS Catal. 8, 1325-1337 (2018)

37. Wei, L., Yao, D.W., Wu, F., Liu, B., Hu, X.H., Li, X.W., Wang, X.L.: Impact of hydrothermal aging on $\mathrm{SO} 2$ poisoning over $\mathrm{Cu}$ SSZ-13 diesel exhaust SCR catalysts. Ind. Eng. Chem. Res. 58, 3949-3958 (2019)

38. Su, W., Chang, H., Peng, Y., Zhang, C., Li, J.: Reaction pathway investigation on the selective catalytic reduction of $\mathrm{NO}$ with $\mathrm{NH} 3$ over Cu/SSZ-13 at low temperatures. Environ. Sci. Technol. 49, 467-473 (2015)

39. Szanyi, J., Kwak, J.H., Zhu, H., Peden, C.H.F.: Characterization of Cu-SSZ-13 NH3 SCR catalysts: an in situ FTIR study. Phys. Chem. Chem. Phys. 15, 2368-2380 (2013)

40. Zhang, R., McEwen, J.-S., Kollár, M., Gao, F., Wang, Y., Szanyi, J., Peden, C.H.F.: NO chemisorption on Cu/SSZ-13: a comparative study from infrared spectroscopy and DFT calculations. ACS Catal. 4, 4093-4105 (2014)

41. Ruggeri, M.P., Nova, I., Tronconi, E., Pihl, J.A., Toops, T.J., Partridge, W.P.: In-situ DRIFTS measurements for the mechanistic study of $\mathrm{NO}$ oxidation over a commercial Cu-CHA catalyst. Appl. Catal. B Environ. 166-167, 181-192 (2015)

42. Negri, C., Hammershøi, P.S., Janssens, T.V.W., Beato, P., Berlier, G., Bordiga, S.: Investigating the low temperature formation of CuII-(N, O) species on Cu-CHA zeolites for the selective catalytic reduction of $\mathrm{N}_{\mathrm{O}} \mathrm{x}$. Chem. Eur. J. 24, 12044-12053 (2018)

43. Bensitel, M., Saur, O., Lavalley, J.C., Mabilon, G.: Acidity of zirconium oxide and sulfated $\mathrm{ZrO}_{2}$ samples. Mater. Chem. Phys. 17, 249-258 (1987)

44. Burch, R., Watling, T.C.: The effect of sulphur on the reduction of $\mathrm{NO}$ by $\mathrm{C}_{3} \mathrm{H}_{6}$ and $\mathrm{C}_{3} \mathrm{H}_{8}$ over $\mathrm{Pt} / \mathrm{Al}_{2} \mathrm{O}_{3}$ under lean-burn conditions. Appl. Catal. B Environ. 17, 131-139 (1998)

45. Waqif, M., Saad, A.M., Bensitel, M., Bachelier, J., Saur, O., Lavalley, J.C.: Comparative study of $\mathrm{SO}_{2}$ adsorption on metal oxides. J. Chem. Soc., Faraday Trans. 88, 2931-2936 (1992)

Publisher's Note Springer Nature remains neutral with regard to jurisdictional claims in published maps and institutional affiliations. 